\title{
Introducción al pensamiento cristiano y religioso de Galdós
}

\author{
Antonio Aparisi LAPORTA ${ }^{1}$
}

Fecha de recepción: Abril 2019.

Fecha de aprobación: Enero de 2020.

\section{Sumario:}

Pérez Galdós debiera ser considerado el mejor exponente de la narrativa española, junto a Cervantes, por su riqueza lingüística descriptiva y analítica de la complejidad y grandeza del ser humano; conjugando ficción, símbolo y veracidad documental a lo largo de una ingente producción durante cincuenta años. Pero, así mismo, por la hondura del tratamiento religioso y cristiano que da al mundo literario testimonial creado por él; también por el carácter profético de su teología.

El artículo, de carácter introductorio y sugeridor, reclama una atención a esta dimensión de la obra galdosiana por parte de los responsables de redescubrir, guardar amorosamente y restablecer en nuestro país legados culturales que nos alimenten. En particular, por parte de quienes hacen revivir la historia de la teología y del patrimonio cristiano con la impronta de lo narrativo, lo simbólico y lo profético.

\section{Palabras clave:}

Galdós, Patrimonio, Teológico, Cultural, Cristiano.

\section{Introduction to the christian thought And religious of Galdos}

\begin{abstract}
:
Pérez Galdós should be considered the best exponent of the Spanish narrative, with Cervantes, for his descriptive linguistic richness and analytical of the complexity and greatness of the human being; combining fiction, symbol and documentary truthfulness throughout a huge production for fifty years. But, likewise, for the depth of the religious and Christian treatment given to the testimonial literary world created by him; also for the prophetic character of his theology.

The article, of an introductory and suggestive nature, demands attention to this dimension of the Galdosian work by those responsible for rediscovering, lovingly saving and restoring in our country cultural legacies that feed us. In particular, by those who revive the history of theology and Christian heritage with the imprint of the narrative, the symbolic and the prophetic.
\end{abstract}

\section{Keywords:} Christian.
Galdós, Heritage, Theological, Cultural,

\footnotetext{
${ }^{1}$ Doctor en Humanidades (Universidad de Carlos III de Madrid). http://ORCID.ORG/0000 0003-4468-1744<antonioaparisi@hotmail.com>
} 


\section{Introducción}

La obra de Benito Pérez Galdós constituye un mundo riquísimo y complejo de temas antropológicos e históricos. Entre ellos, con un carácter transversal y determinante, se halla el pensamiento religioso tal como se manifiesta, se desenvuelve y se ahonda en el ser humano y, particularmente, en el ciudadano español y en la expresión hispana del catolicismo.

Nuestra exposición del mismo va a ser aquí -por razones de brevedad-sucinta y esquemática, con un carácter sólo introductorio y sugeridor de mayor y más detenido estudio. Las citas textuales del escritor se van a reducir al mínimo, mostrando, sin embargo, a título de ejemplo, su presencia a lo largo de los tres géneros que mejor lo identifican (novelas independientes, episodios nacionales y piezas teatrales) ${ }^{2}$.

He de confesar que me siento apasionado por la obra toda de Galdós y, por tanto, en algún modo, del autor mismo. Sin embargo, creo que el trabajo que presento se ajusta a la objetividad documental, superando con mucho cualquier apreciación o intencionalidad subjetivas.

Creo conveniente hacer ahora dos aclaraciones previas al tratamiento de nuestro tema: primera, indicar la razón por la que -a mi juicio-resulta todavía necesario indagar y detenerse en el estudio más amplio y de mayor calado de la temática religiosa existente en la obra de Galdós; y segunda, explicar cómo debe entenderse e incluir aquí la expresión "temática religiosa" al aplicarla a esa ingente creación literaria, seguramente la más desarrollada y densa de nuestras Letras.

\subsection{Razones para abordar la dimensión religiosa y cristiana en la obra de} Galdós

Por qué indagar y, si procede, expresar el pensamiento religioso y cristiano existente en la amplísima creación de Don Benito y por qué ofrecer este trabajo al foro de estudios galdosianos.

Para todos nosotros es obvio que la identidad de Galdós es la literatura: nuestro escritor canario pertenece por derecho absoluto y preeminente al mundo literario. Entendiendo por literatura la belleza y la significación máxima de

\footnotetext{
${ }^{2}$ Para un mejor conocimiento del tema me remito a mi libro. La perspectiva teológica en el pensamiento galdosiano. Galdós, patrimonio cultural cristiano. (Edición Luis M. Aparisi. Madrid 2015, 909 pp.), Accesible en Biblioteca Nacional y en Biblioteca virtual de la Universidad Carlos III de Madrid.
} 
la lengua, el hondo testimonio escrito acerca del drama del ser humano en su totalidad individual y colectiva; en consecuencia, la aproximación e interpretación fiel de la historia y, en fin, la oferta de un patrimonio cultural saludable para el futuro de un país o de la Humanidad.

Estas cuatro dimensiones de la identidad literaria (lingüística, antropología, historia y pedagogía) se plasman y desarrollan en la creación galdosiana según una serie de ejes transversales que recorren, sostienen y en ocasiones vertebran sus abundantísimos escritos de todo género, especialmente en los Episodios Nacionales y en las novelas independientes.

A mi juicio tales ejes son:

- El análisis -diríamos que exhaustivo- de la realidad dramática del individuo, del español en concreto, en su admirable heterogeneidad y en su avatar histórico;

- la metahistoria de España, la integración del complejo pasado hispano en el presente, y la transcripción de ambos en orden a un futuro que resulta incierto;

- la dimensión religiosa crítica, sobre todo en referencia al catolicismo hispano (tanto individualizado como eclesial), en cuanto importante cuestión pendiente;

- e indudablemente una gran propuesta educativa, una pedagogía fundamental para españoles.

Todas sus obras (novelas independientes, Episodios Nacionales, piezas de teatro, ensayos, discursos, artículos de prensa, comentarios propios de algunas de sus obras y epistolario) se articulan conforme a estos ejes.

Pues bien, he querido centrarme en la dimensión religiosa del pensamiento galdosiano.

No lo hago por un motivo particular de signo religioso; tampoco me mueve el deseo de rehabilitar la figura de Galdós ante el mundo católico español. Aunque todo ello merezca interés. Me mueven a realizar este trabajo sencillamente varias otras razones que considero de suficiente importancia.

$1^{a}$ razón. La densidad misma del pensamiento cristiano y religioso en la casi totalidad de la creación galdosiana. Hecho al que, sin embargo, a mi juicio, todavía le falta mayor consideración (por parte de los estudiosos del escritor).

Tras la lectura de años -lectura reposada y gozosa- de toda la creación literaria de Galdós, debo manifestar la sorpresa personal de haber encontrado en ella una inesperada, abundante y profunda temática de signo religioso universal y de signo cristiano particular; más aún, una excepcional trascripción narrativa de la ética de los Evangelios. Es un hecho desconocido en el resto de nuestra literatura y, más en concreto, en la literatura del realismo que, sin 
embargo, sí aborda con notable seriedad la temática religiosa (pensemos en las novelas de Valera, Pereda, Clarín, Cecilia Böhl de Fáber, Palacio Valdés, Pardo Bazán...).

Creo que Galdós es único en este aspecto.

Una prueba de ello es el número considerable de trabajos serios sobre aspectos diversos o enfoques globales de la religiosidad y de la moral evangélica en las obras de Galdós, desde la publicación de Stephen Scatori de 1926 hasta la actualidad; algunos en libros dedicados exclusivamente al tema y muchos otros, la mayoría, como trabajos monográficos aparecidos en las Actas de los congresos internacionales de estudios galdosianos, en las magníficas revistas Anales Galdosianos, Isidora, y en otras publicaciones periódicas. He tenido la oportunidad de poder leer o simplemente recensionar 82 de estos libros o trabajos (según manifiesto en la publicación de mi tesis doctoral). Teniendo en cuenta, además, que en los notables estudios generales sobre Galdós y su obra se considera también la dimensión religiosa.

No obstante, a pesar de la excepcional aportación que supone esa copiosa tarea investigadora y publicista, he echado en falta siempre un estudio de tal dimensión religioso y cristiana más completo y exhaustivo, pero, sobre todo, más global y a la vez pormenorizado y cohesionado; un estudio no limitado a la consideración de obras concretas o de aspectos parciales del tema, sino extendido a la totalidad de los escritos de todo tipo del autor y a las múltiples facetas de la teología conexas entre sí en esa creación galdosiana.

Entendiendo que esta laboriosa atención -al verificarla- nos permitiría disponer mejor de las claves de interpretación y de valoración del conjunto de su literatura.

(Quizás en este asunto ocurra algo semejante a lo que ha sucedido en otras áreas de la cultura artística actual española, en las que -no sabemos exactamente por qué prejuicio- bastantes ilustrados omiten la perspectiva religiosa; valga de ejemplo lo que ocurre en cuanto a la pintura de Goya: seguramente son muy pocos los que conocen y valoran la existencia de unas doscientas obras de tema religioso en la producción goyesca, ignorando, al parecer, que una parte de ellas revela precisamente la técnica original de su pintura.)

Un lector imparcial de todos los escritos de Don Benito no puede sustraerse a la sorpresa de la abundancia y densidad de la temática religiosa en ellos. En ese momento se siente empujado a indagar y a penetrar lo más posible en la complementaridad interna de tal dimensión respecto al pensamiento del autor, llegando tal vez a descubrir ahí un verdadero fondo teológico.

A este trabajo he consagrado una buena parte de mi vida, porque creo que merecía la pena hacerlo. 
$2^{\mathrm{a}}$ razón. El significado actual que tiene el pensamiento religioso de Don Benito para la cultura española.

Una primera constatación al adentrarse en la producción galdosiana es la existencia de un nexo integrador de todas las dimensiones que desarrollan sus escritos. No hay fragmentación en la estructura de una obra ni en el conjunto de obras (como si un aspecto -el histórico, por ejemplo- fuera asunto paralelo e intranscendente en la dramática del protagonista). No. Todo viene integrado y todo contribuye a la madurez de los personajes y de los escritos, entrelazándose admirablemente.

La hermenéutica de esta creación no es demasiado difícil: Galdós, penetrando agudamente en el presente y en el pasado de nuestro ser hispano, interpela con asombrosa claridad al futuro, que es ya nuestra propia realidad, y advierte los pesos que gravitan sobre nuestro devenir social, político, moral y religioso.

Porque el quehacer y el drama de sus personajes (del signo que sean) no sólo los identifica en su contexto histórico, sino que forman parte de la historia íntima que nos ha llevado y traído como una genética que persiste, que no ha sido aún rehecha y resuelta, por más que quieran soslayarse y olvidar aspectos sustanciales de la misma. Como lo sería - lo es-el factor religioso hispano, determinante de todos los siglos que nos preceden y nos acompañan... (Un factor que en la actualidad apenas tiene constancia alguna, desprovisto de relevancia en el devenir individual, cultural, social o político.; pero que no se plantea así en el mundo que contempla y analiza Galdós, que -insistimos- continúa siendo el nuestro).

En el ensayo que titula El sentimiento religioso en España escribe:

«Durante siglos, ni una idea sola ha sido independiente de aquella idea madre (la idea religiosa), ni fuerza alguna ha obrado separada de aquella fuerza elemental», -y prosigue con tonos encendidos-: «San Juan de la Cruz hace los versos más sentidos que posee nuestra lengua, mientras el pintor Juan Masip comulgaba para pintar mejor, y no cogía la paleta sino cuando sentía absolutamente limpia su conciencia» ${ }^{3}$.

Coherente con esta idea, introduce en el Episodio España sin rey el famoso discurso de Emilio Castelar -como liberal- en las Cortes de 1869 y primer presidente de la estrenada República.

«Hay un Dios más grande todavía, que no es el majestuoso Dios del Sinaí, sino el humilde Dios del Calvario, clavado en una cruz, herido,

${ }^{3}$ B. Pérez Galdós, El sentimiento religioso en España, en Las cartas desconocidas de Galdós en La Prensa de Buenos Aires, ed. W. Shoemaker (Madrid: Cultura Hispánica, 1973), 146-147. 
yerto, coronado de espinas, ...Grande es la religión del poder; pero es más grande la religión del amor. Grande es la religión de la justicia implacable; pero es más grande la religión del perdón misericordioso; y yo, en nombre de esta religión, en nombre del Evangelio, vengo aquí a pediros que escribáis al frente de vuestro Código fundamental la libertad religiosa, es decir Libertad, Fraternidad, Igualdad entre todos los hombres» ${ }^{4}$.

Galdós entiende sin dificultad que el debate religioso público era necesario para el país, en cuanto que lo religioso (la libertad de cultos, en concreto) constituía un factor importante para contrapesar el frágil equilibrio de la sociedad española del XIX. (Imagínense Vds. un discurso semejante hoy en nuestro Congreso de Diputados...). Y el escritor desea dejar constancia de que un pensamiento positivo de original signo cristiano o simplemente religioso está llamado a configurarse como aportación pública lúcida al crispado clima de nuestra política nacional. Más aún, que la ciudadanía de este país tiene derecho a esperar una palabra sensata de instancias religiosas, siempre que estas se hallen dignificadas (como en tiempos del cardenal Tarancón, diríamos) por el testimonio de la trayectoria personal evangélica, honesta, sabia, abierta e independiente de poderes económicos; una palabra como la que pronuncia el alto eclesiástico Muñoz Torrero en la apertura de las Cortes de Cádiz (narrada en el Episodio Nacional Cádiz):

«Las palabras se destacaban sobre un silencio religioso, fijándose de tal modo en la mente que parecían esculpirse. La atención era profunda, y jamás voz alguna fue oída con más respeto... En un cuarto de hora Muñoz Torrero había lanzado a la faz de la nación el programa del nuevo gobierno y la esencia de las nuevas ideas. Cuando la última palabra expiró en sus labios y se sentó, recibiendo las felicitaciones y los aplausos de las tribunas, el siglo XVIII había concluido. El reloj de la historia señaló con campanada, no por todos oída, su última hora, y realizóse en España uno de los principales dobleces del tiempo» ${ }^{5}$.

Sin deteriorar la laicidad del estado y de su gobierno, sin permitir intromisiones propias de épocas pasadas, este país debiera contar en su haber-según Galdós-con una palabra dicha a su favor por la instancia religiosa. Ese pudiera ser el sentido primordial (no único) del pensamiento religioso que brota en la obra que analizamos.

\footnotetext{
${ }^{4}$ B. Pérez Galdós, España sin rey (Madrid: Historia 16-Caja Madrid, 1996), 72-73.

${ }^{5}$ B. Pérez Galdós, Cádiz (Madrid: Alianza Editorial, 1996), 61.
} 
$3^{a}$ razón. El valor del pensamiento galdosiano como teología alternativa valiosa para el mundo cristiano.

A mi modo de ver Don Benito tiene una palabra autorizada dirigida al mundo católico de su tiempo y al presente y futuro de la Iglesia. Como veremos después, es importante señalar el hecho de que Galdós propone-desde la secularidad- una serie de posibles revisiones ideológicas y de comportamientos que las instituciones cristianas y los creyentes harían muy bien en estimar para su propia reforma; quizás en la frontera de cierta heterodoxia algunas de ellas, es verdad, pero - en conjunto- dentro de una seria interpretación de las fuentes bíblicas y de la tradición eclesial que el autor domina suficientemente. Situando su pensamiento en un hipotético Vaticano III más abierto aún que el II.

Ésta es la constatación a la que fui llegando a lo largo del encuentro con la producción galdosiana.

En todo caso, no dudo en situar y proponer a nuestro autor como parte del patrimonio cultural cristiano contemporáneo, al menos en España.

\subsection{La dimensión religiosa cristiana que se indaga}

Los términos religioso y cristiano adolecen de cierta ambigüedad en el habla, sobre todo cuando se entremezclan. De entrada, a la teología le resulta necesario distinguir el pensamiento cristiano del pensamiento religioso. Se trata de dos niveles distintos (incluso de dos áreas distintas) de ideas, de experiencias y de comportamientos; aunque lo cristiano incluya también -si es fiel a sí mismo- un elevado nivel de religiosidad.

Lo religioso indica sólo una cierta referencia al mundo transcendente personalizado, a Dios, a una idea de Dios (que puede ser diversa en unos y en otros, de todo saludable o perjudicial). Lo cristiano, en cambio, se mide fundamentalmente por la ética del Evangelio puro (portador, sin duda, de altos valores humanos) y por la idea amable, espiritual y redentora del Dios de Jesucristo.

En todo caso, indagamos en la obra de Galdós tres niveles de exposición del pensamiento con valoración religiosa y cristiana:

$1^{\text {er }}$ nivel. La ética, que en sí misma tiene una significación religiosa implícita.

Un modo casi espontáneo de sentir la conciencia, de pensar y de proponer la existencia personal con un tono claramente evangélico. Y esto en dos niveles posibles de consciencia que poseen los diversos personajes del mundo galdosiano con los que se identifica claramente el autor: 
- En función de una ética natural interiorizada y dotada de valores coherentes con el proyecto de Jesús, aunque no se refiera a éste de forma explícita ni a ninguna categoría religiosa.

- O manifestando valores naturales o supernaturales de moralidad expresamente referidos al cristianismo o a formas diversas de religiosidad saludable; en cuyo caso esta ética elevada incluye tácitamente una dimensión religiosa porque verifica dos hechos claros para Galdós:

- Que la búsqueda honesta de humanismo y las cotas de humanidad que se van logrando tienen en sí mismas un valor religioso y cristiano en cuanto que coinciden -como algo constitutivo- con el proyecto de Jesús de Nazaret; y, por tanto, son la base esencial de cualquier idea y comportamientos que se pretendan religiosos o cristianos.

- Y, a la inversa, que el proyecto moral de Jesús, (el Evangelio tal como Jesús mismo lo vive y como lo propone a sus seguidores) aporta una garantía de humanismo integral; un humanismo deseado por el Dios de Jesús, ofreciendo esa ética la identidad religiosa fundamental.

$2^{\circ}$ nivel. El pensamiento religioso directo.

Se trata de ver en qué términos establece el autor la relación personal explícita con la Trascendencia, con Dios; coincida o no esta idea de Dios con la que expresa Jesucristo, con el Dios del cristianismo, o con otro concepto de la divinidad y de lo trascendente (quizás de signo krausista), y sea tal relación tensa y dramática o adquirida y serena.

\section{$3^{\text {er }}$ nivel. El pensamiento acerca de las instituciones religiosas.}

La consideración y la crítica de las instituciones religiosas y de sus manifestaciones; en particular, la visión del catolicismo dominante y de su reforma.

Iniciada la lectura de la creación galdosiana comprobamos enseguida que esos modos diversos éticos y religiosos de sentir, de pensar y de expresarse están patentes en una notable mayoría de personajes creados y amados por el autor; en muchos casos intensamente, con extraordinaria riqueza descriptiva y analítica de tipos variopintos. Desde Marianela, la inocente y amante Nela, la sin nombre, hasta el poderoso y desgraciado Torquemada, que -también en el lecho de muerte- se relaciona con Dios, pero sólo para comprarle a precio de saldo su propia salvación, y al que Galdós -identificado con Gamborenaintenta salvar. Pasando por espléndidas figuras profundamente religiosas y morales como Leré (de Angel Guerra), Nazarín, Benina, Catalina de Artal, Juana de Castilla, Mariucha, Sor Simona, Electra, los ancianos locos de los Episodios... y otros que el autor considera santos. 
Es decir:

- Unas veces lo ético-religioso se halla bien integrado en el estatuto caracterial del individuo de forma positiva y serena (los tipos novelados o escénicos con este perfil son innumerables y magníficos), casi siempre en cierta tensión anímica crítica (pensemos, por ejemplo, en Gabriel e Inés, Sola, Salvador Monsalud, Demetria y Gracia, Fernando Calpena y Santiago Íbero, Benigno Cordero..., de los Episodios; en Clara y Lázaro, Leré, Catalina de Artal, Don Nazario, Tomé, Juan Casado, Nones, Gamborena, Rosaura..., en las novelas independientes...; en María -la de Voluntad y de Mariucha-, Máximo, Pedro Minio, Santiago Paternoy -Los condenados-,... en el teatro);

- Otras, en situación de crisis aguda que se prolonga hasta resolverse con algún acierto espiritual (pensamos en Salvador Monsalud, Pepe Fajardo, Juanito Santiuste, José Fago... en los Episodios; en Gloria Y Daniel Morton, Rosario, Rosalía y Horacio Reynolds, Ángel Guerra, Marianela, José Antonio Urrea, Fortunata y Jacinta, Tristana, Amparo..., en la novela independiente; Electra, Victoria, la ex reina Juana de Castilla o Sor Simona en el teatro, incluso Casandra...);

- Y en no pocas ocasiones lo religioso aparece trágicamente superpuesto a la personalidad, dislocándola y amenazando su estatuto moral y social, generando con frecuencia tragedias irreparables (recuérdese la familia Lantigua, de Gloria, Juan Crisóstomo de Rosalía, Doña Perfecta, María Sudre, de La familia de León Roch, Pantoja, de Electra, Doña Juana de Casandra, las Porreño, de La Fontana de Oro, Torquemada, los eclesiásticos Pedro Polo, Don Inocencio, Paoletti y Gonzalo, José Fago y bastantes más).

Todos ellos - unos y otros- tienen en su trayectoria personal un fuerte integrante religioso que generalmente les conduce a una ética de signos diversos, mayoritariamente cristianos o, de manera muy expresa anticristianos.

Dos últimas observaciones:

$1^{\text {a }}$. Galdós vive -se encarna- en sus personajes. Crea y mantiene con ellos un mundo familiar de alguna manera primordial. Los ama a todos, buenos y malos, de izquierdas o de derechas, agraciados y desgraciados (como Isidora la desheredada o la Nela, el avaro Torquemada o María Sudre, la fracasada esposa de León Roch, o el general Zumalacárregui). Y su forma de pensar se expresa en ellos o con ellos; pero se manifiesta por la identificación o desidentificación ideológica, más allá de la relación emotiva. De ahí que sea importantísimo llegar a percibir esa relación sutil del autor con la mentalidad del personaje, a través de la lectura detenida y comparada, teniendo en cuenta -sobre 
todo- las manifestaciones directas del escritor cuando éste habla por sí mismo -o de sí mismo- en el escrito.

$2^{\text {a }}$. Galdós usa la figura literaria del retruécano: afirma presentando un texto o una situación inadmisible. Por ejemplo, lo que piensa sobre la Iglesia aparece con mucha más frecuencia al manifestar aquello que -según él-no debiera ser la Iglesia. Obras enteras, como Rosalía, Gloria, Casandra, Doña Perfecta, La familia de León Roch, y, en general, las dos últimas series de los Episodios emplean este artificio literario. Porque el lector entiende sin dificultad que lo que sucede en todas ellas es exactamente lo que no debiera suceder en el cristianismo ni en ninguna religión clásica. De lo cual se deduce -en particular- su pensamiento sobre la verdad de la fe cristiana cuya presencia no descarta para la construcción de la sociedad.

Y resulta obvio que los catolicísimos personajes Doña Perfecta, Don Inocencio, Doña Juana de Casandra, Juan Crisóstomo, Pipaón, Pantoja, Fernando VII y Carlos Isidro, Don Hilario, el arcipreste Juanhondón (que se hace ayudar en la Misa por las mujeres a las que tiene esclavizadas), la gran mayoría del clero galdosiano en general..., todos estos, están mostrando con su conducta o sus ideas aberrantes cuál es -en sentido contrario- el verdadero pensamiento del autor sobre Dios, Iglesia o cristianismo. Tanto o más que si lo expusieran personajes verdaderos creyentes.

Dicho lo cual, estructuro y resumo esta breve exposición en dos partes: primera, lugares teológicos de la literatura galdosiana y, segunda, ejes axiomáticos de su pensamiento religioso.

\section{Lugares literarios principales de lo religioso y lo cristiano en la crea- ción galdosiana. Densidad y fuentes de inspiración de los mismos}

¿En dónde y con qué densidad aparece el pensamiento cristiano de Don Benito?

En síntesis, se puede afirmar que aparece detenidamente en las obras formales (narrativa, teatro) a lo largo de toda su producción durante los más de cincuenta años en que ésta se elabora. La lectura sosegada de estos escritos y del enorme caudal de artículos, ensayos largos, conferencias y cartas del autor nos deja la impresión de que la temática religiosa y moral tenía un hondo asentamiento en su quehacer literario. Su pluma fundamentalmente humanista y retrato fiel de la realidad histórica, rezuma al mismo tiempo espiritualidad, vivencias religiosas, referencias bíblicas y cuestiones teológicas.

Pero no por igual siempre en cuanto a la dedicación e intensidad temáticas. 


\subsection{Lugares y densidad del pensamiento religioso y cristiano en la obra de Galdós}

Conviene distinguir objetivamente series distintas de escritos según la densidad de esa perspectiva religiosa y cristiana.

a) Obras principales de temática religiosa y cristiana: Serie de escritos literarios largos cuya temática es fundamentalmente religiosa, afrontando a la vez detenidamente la dimensión moral que brota de esa vivencia, las más de las veces crítica ("agónica" en la expresión unamuniana). En estos escritos esa temática conduce y estructura la composición literaria. Pueden considerarse como tales los siguientes:

- Novelas independientes: Doña Perfecta, Rosalía, Gloria, La familia de León Roch, Torquemada y San Pedro.

- Novelas espiritualistas: Nazarín, Halma, Ángel Guerra, Misericordia.

- Episodios Nacionales: Zumalacárregui, El terror de 1824, Aita Tettauen.

- Teatro: Electra, Casandra, Amor y ciencia, La loca de la casa, Santa Juana de Castilla, Sor Simona, Alceste.

- Ensayos: El sentimiento religioso en España. Santos Modernos.

- 20 obras. Estimación personal aproximada $=$ un $18 \%$ (sobre 116 obras formales).

b) Obras sólo de eje transversal religioso: Serie de obras formales en las que aparece la temática religiosa y cristiana en el desarrollo del escrito como un eje transversal más, aunque importante, pero sin que tal perspectiva adquiera el carácter fundante de la obra.

- Novelas independientes: El audaz, La fontana de oro, Fortunata y Jacinta, Tormento, Marianela, Lo prohibido.

- Episodios Nacionales: la $1^{\mathrm{a}}$ y $2^{\mathrm{a}}$ serie (al menos cinco Episodios de cada serie), Tormentas del 48, Aita Tettauen, Cánovas...

- Teatro: Pedro Minio, Los condenados, Mariucha, Voluntad.

- Ensayos: Soñemos, alma, soñemos, Memorias de un desmemoriado.

-25 obras. Estimación aproximada $=23 \%$ (Sobre 116 obras formales).

Lo que significaría un $43 \%$ de escritos formales con importante temática religiosa. En los artículos de prensa y ensayos aparecen también con frecuencia comentarios críticos especialmente a propósito de la religiosidad popular, de la situación religiosa del país o de los acontecimientos eclesiales ${ }^{6}$.

\footnotetext{
${ }^{6}$ Pueden verse: William H. Shoemaker, Las cartas desconocidas de Galdós en «La Prensa» de
} 
Puede afirmarse, pues, que en un porcentaje elevado del conjunto de obras emblemáticas de Galdós existe un pensamiento con densidad teológica. Lo que nos permite creer que nos hallamos ante un pensador que habría que situar seguramente en la historia de la teología como un literato teólogo que ha intentado aproximar el hecho religioso a sus conciudadanos y al futuro de su pueblo de una manera bella, seria y elocuente; y, en todo caso, como una aportación ineludible al patrimonio cultural de signo cristiano en España.

¿Qué frecuencia, expresividad y densidad alcanza ese pensamiento en la creación galdosiana?

Me permito señalar que mi propio trabajo sobre el mundo galdosiano me ha llevado fácilmente a seleccionar, a transcribir y analizar 929 citas textuales de referencia religiosa cristiana del autor.

Estas citas pertenecen: 360 a las novelas independientes, 361 a los Episodios Nacionales, 95 al teatro, 113 a otros escritos.

A título casi anecdótico, refiriéndome sólo a las novelas, puedo mostrar esta tabla de citaciones seleccionadas significativas:

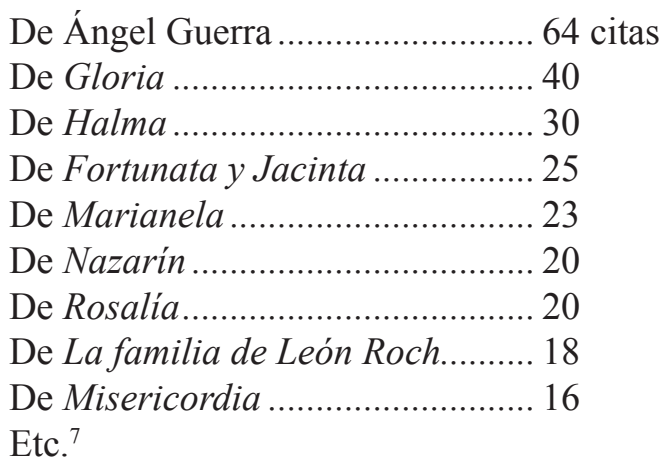

En estos textos existen con la mayor frecuencia las siguientes características:

- Claridad y belleza lingüística, literaria.

- Penetración en la trama vivencial interior del personaje -siempre representativo de la realidad-mostrando sus estados diversos de ánimo respecto a la Trascendencia.

Buenos Aires. (Madrid: Ediciones Cultura Hispánica, 1973). William H. Shoemaker, Los artículos de Galdós en «La Nación» 1865-1866 y 1868. Recogidos, ordenados y dados nuevamente a la luz con un estudio preliminar (Madrid: Ínsula, 1972). Robert Ricard, «Cartas a Galdós y cartas de Galdós», Anuario de Estudios Atlánticos, 11 (1965): 163-191.

${ }^{7}$ Pueden verse estas citas en mi libro La perspectiva teológica en el pensamiento galdosiano. Col. Biblioteca digital de la Universidad Carlos III de Madrid, Departamento de tesis doctorales (Madrid. 2016). 
- Conocimiento objetivo de la teología cristiana (tácito o expresamente mostrado) y pormenorizado en los múltiples aspectos con los que se presenta en el Nuevo Testamento; y, así mismo, de la moral evangélica.

Es decir, tales textos tienen a la vez una notable densidad literaria y teológica; permitiéndonos hablar de una verdadera y ejemplar teología narrativa y simbólica.

Por su parte, en el epistolario galdosiano y en escritos de índole más personal del autor aflora con cierta naturalidad en bastantes ocasiones ese pensamiento, aunque se exprese de manera más tenue y no sea frecuente, pero sí más íntimo (como cuando, conseguido el estreno de la versión teatral de Marianela por los Álvarez Quintero, esperada tanto tiempo por Galdós ya anciano, éste escribe emocionado: «Ahora, Dios sobre todo» ${ }^{8}$.

\subsection{Fuentes de conocimiento del pensamiento teológico de Galdós}

Es cierto que Don Benito era un genio del pensamiento cuando contemplaba el ser humano y la realidad social.

(Podría testimoniar, como ejemplo, el asombro que produce a profesionales de la psiquiatría los análisis agudos de patologías mentales y emocionales que hallamos en la novelística galdosiana, bastante antes de los estudios de Freud. Pensemos en Isidora, en las atormentadas Amparo, Tristana, Electra, en la caracteriología de Juanito Santacruz, Patricio Sarmiento, Santiuste o Tito, etc.; tanto que ha hecho interrogarse a esos técnicos de la salud mental sobre los estudios de psicología clínica o de psiquiatría que hubiera podido cursar Galdós. ¿Qué estudios cursó Don Benito al respecto? ¡Ninguno! Y tampoco en su biblioteca encontramos tratados de estas materias que, por otra parte, eran aún muy escasas e inalcanzables a la altura de finales del siglo XIX. ¿A qué se deben, pues, esos análisis tan geniales como los de la locura o de la interioridad del alma humana de diversos personajes de sus obras? ¡Sólo a su capacidad observadora e intuitiva excepcional! No hubo más).

Al referirnos ahora al pensamiento religioso no cabe duda de que esa genialidad persiste. Pero aquí resulta que sí encontramos un respetuoso salto hacia el estudio de las fuentes del conocimiento teológico en su estado más puro.

a) Galdós estudió la Biblia, particularmente el texto de los Evangelios, pero también todos los libros de la Escritura. La cita abundantemente con una coherencia absoluta de los textos referidos. En la novela Gloria apare-

${ }^{8}$ B. Pérez Galdós, Carta de 4/7/1916 desde Santander (C. Doc. Casa Museo. no 8085). 
cen 40 citas bíblicas; Misericordia sigue la estructura del Evangelio según San Mateo, citando cinco veces el Sermón de la Montaña. Una parte de la fraseología de Nazarín es literalmente evangélica (al mismo tiempo que cervantina).

La onomástica de muchos de sus personajes centrales y de los hechos narrados es sustancialmente bíblica, sobre todo a propósito de la Pasión, Muerte y Resurrección de Jesús y de su obra redentora. El todavía agnóstico Guillermo (Amor y ciencia) toma en brazos al bebé abandonado en la calle y -misteriosamente-, como el anciano bíblico Simeón, pronuncia sobre el niño el más bello bautismo: «Te llamarás Salvador», y desde esa hora el pequeño será para él «su Niño Dios», quien rehace el matrimonio roto y se hermana con el hijo natural Cristín.

Estudió a comentaristas avanzados de la época como Lammenais, y, libre de toda presión dogmática vaticana, buscó la interpretación justa de los postulados cristianos originales que surgen del evangelio de Jesús, distanciándose de los más comunes de la devoción moderna (tan conocidos como los de Tomás de Kempis o de San Francisco de Sales, citados ambos autores en Rosalía).

Para esa interpretación bíblica Galdós se acercó seriamente a la lectura de los Santos Padres. Cita textualmente a escritores cristianos de los primeros siglos: San Juan Crisóstomo, San Basilio, San Gregorio de Nisa y San Gregorio Nacianceno, San Ambrosio..., la mayoría de estos comentados en El caballero encantado; en general como textos de crítica social fuerte, (quizás silenciados por el magisterio eclesiástico posterior). Especialmente se refiere a San Agustín (en sus Confesiones) en la novela Halma, donde, además, se trascribe en el personaje José Antonio Urrea el proceso de conversión del santo de Hipona.

Y sin duda alguna el pensamiento teológico de Galdós se fecunda en el krausismo español de inspiración religioso cristiana universalista, introducido por Julián Sanz del Río que traduce El ideal de la Humanidad, y a quien siguen Francisco Giner de los Ríos, Azcárate, Castelar y el mismo Don Benito.

b) A la vez, Galdós se debe al simbolismo religioso. De alguna forma es un literato que -en toda su producción- conduce el realismo hacia la integración del simbolismo, que se desarrolla en toda su obra en dos dimensiones:

- En la semántica: onomástica y, con frecuencia, toponimia, es decir, en los nombres de personajes y de lugares ficticios (pero con asiento realista) en los que se mueve según interese a las tramas narradas. También en títulos de algunas obras (Misericordia, Nazarín, Gloria, Tormento, Lo prohibido, Torquemada y San Pedro...). 
- Y, sobre todo, en las tramas o acciones narradas y en las trayectorias personales de los personajes; incluso recurriendo a parábolas del clasicismo griego reinterpretadas cristianamente, como en las piezas teatrales Bárbara y Alceste, que -en el caso de esta última- el mismo Galdós ve como trasunto de la muerte y resurrección de Jesús. Gustavo Correa, y Francisco Ruiz Ramón... han escrito libros muy reveladores sobre las acciones o tramas simbólicas en las obras de Don Benito.

Una gran parte de este simbolismo es bíblico o de la más pura tradición cristiana. Entre otros, recordando sólo los que evocan realidades valiosas moral y religiosamente: Ángel Guerra, Benigno Cordero, Benina, Clara, Gabriel de Araceli, Gloria, Gracia, (H)alma, Inés, Lázaro, Marqués de los Perdones, Misericordia, Nazario, Nuestra Señora de la Indulgencia, Salvador Monsalud, etc. Entre los lugares bíblicos: Jerusa (El abuelo), Babel (Ángel Guerra)...

En cuanto a las tramas de inspiración bíblica recordemos las realidades evocadas o encarnadas por los siguientes hechos simbólicos:

- La vida, modo de ser y desarrollo existencial de Jesús en novelas como Nazarín, Misericordia, Halma, en el drama Alceste, etc.

- La agonía cristiana (el combate de la fe, la lucha paulina entre el hombre nuevo y el hombre viejo) en Ángel Guerra, Tormento, Torquemada y San Pedro, Lo prohibido, Casandra (teatro y novela), las segunda y tercera series de los Episodios.

- La defensa de la libertad cristiana y la lucha por la liberación espiritual en Santa Juana de Castilla, Electra, Sor Simona, El abuelo...

- La evocación del Reino de Dios y de la iglesia apostólica en Halma, Pedro Minio, final de Gloria. Ángel Guerra...

- La misión del presbítero en las iglesias, en todas las novelas de espiritualidad, en el Episodio Zumalacárregui...

- Etc.

\section{Contenido axiomático del pensamiento religioso y cristiano en el con- junto de la literatura galdosiana}

La especialista en temas galdosianos Amor del Olmo escribe acertadamente: «El espiritualismo es lo que más se acerca a la reforma galdosiana, pero tal vez el escritor todavía no sospechaba que, para la sociedad española, todo lo que no fuera catolicismo tradicional e inquisicional, no servía... (...) La reforma social de Galdós, por tanto, iba dirigida 
también a una reforma de los estamentos religiosos, denunciando una falsa religión perniciosa para la sociedad, a cambio de la defensa y búsqueda de la verdad» ${ }^{9}$.

¿Qué temas concretan este pensamiento teológico alternativo de Galdós expresado en su creación e insertos en el mundo literario de personajes queridos o admirados con los que se identifica?

Muchos, sin la menor duda (por no decir casi todos). Vamos a abordar -con penoso esquematismo- las propuestas principales de carácter cristiano y religioso que se desarrollan en la creación galdosiana. A partir de la totalidad de ese mundo, ¿qué teología vertebra en gran medida la literatura de Don Benito?

A mi modo de ver existen dos grandes líneas con ese carácter: $1^{\text {a }}$, la más constante y desarrollada, la teología moral evangélica que conecta con una ética humana fundamental y la perfila y agranda; $2^{\mathrm{a}}$, una cristología clara, aunque no extensa, de la que se deriva una eclesiología ampliamente estudiada.

\subsection{Postulados evangélicos éticos en las obras de Galdós}

A Galdós le preocupa la autenticidad del ser humano, su valía como tal y la superación de sus deterioros morales; es decir su vida real que se desenvuelve siempre en medio de situaciones difíciles, con frecuencia traumáticas. Una ética que tiene la expresa referencia a Jesucristo.

Buenaventura («bienaventuranza»), el más liberal de los Lantigua, configura de este modo su profesión de fe cristiana: «Soy católico, porque veo en Jesucristo, Hijo de Dios, el más admirable ejemplo de perfección moral que puede ofrecerse al hombre» ${ }^{10}$.

Esa perspectiva fundamentalmente moral o humanista (más que dogmática o de trascendencia religiosa) está presente en obras como Fortunata y Jacinta, Lo prohibido, La desheredada, El doctor Centeno, La de Bringas, La incógnita, etc. entre las novelas; en los Episodios Nacionales La segunda casaca, Zumalacárregui, Los duendes de la camarilla, La campaña del Maestrazgo, Aita Tettauen, Cánovas, etc; en las piezas teatrales Casandra, Voluntad, Electra, Mariucha, La razón de la sinrazón, Bárbara, Antón Caballero, Un joven de provecho...; y en relatos breves del tipo de La sombra, Una

\footnotetext{
${ }^{9}$ R. Amor del Olmo, «Religión y evolución: hermenéutica sobre textos dramáticos de Galdós», en Actas del VII Congreso Internacional de Estudios Galdosianos (Las Palmas: Cabildo de Gran Canaria, 2013), 142-145 [Consultado en Biblioteca Virtual Miguel de Cervantes].

${ }^{10}$ B. Pérez Galdós, Gloria (Madrid: Alianza Editorial, 1999), 306.
} 
industria que vive de la muerte... Lo que desea -y no siempre consigue- es que sus hijos alcancen la talla de un verdadero humanismo, lo más hondo y elevado posible, acercándose lo más posible a los valores morales absolutos. Aunque no tengan el sello de lo específicamente cristiano y no vengan acompañados de una consciencia religiosa. Está sugiriendo en el fondo el progresivo cambio de la sociedad hacia lo que Jesús llama «Reino de Dios», un orden humano justo y digno del hombre y de Dios.

Ángel Guerra se lo aclara al sacerdote Juan Casado:

«Don Juan, no sé cómo usted no lo comprende. La aplicación rigurosa de las leyes de caridad, que Cristo Nuestro Señor nos dio, aplicación que hasta el presente está a la mitad del camino entre las palabras y los hechos, traerá de fijo la reforma completa de la sociedad, esa renovación benéfica que en vano buscan la política y la filosofía... Si Dios se hizo Hombre, tiene que hacerse Sociedad ${ }^{11}$.

Lo mismo dirá Juanito Santiuste en el Episodio Aita Tettauen, en un coloquio de aproximación ecuménica entre judíos, musulmanes y cristianos.

Cualquier forma de amor de agapé, de generosidad, será -para nuestro autor- una fuerza de humanización fundamental se viva éste donde se viva y por quien se viva. Pero el amor de la entrega evangélica y de perdón de los enemigos, llevado al nivel de donación absoluta de la propia vida, como lo viven Benina, Don Nazario, Salvador Monsalud, Mariucha y muchos más protagonistas de la escena galdosiana, ese amor, roza, sin duda, la Trascendencia, eleva a la persona al máximo grado de humanidad y transforma el medio social en que ésta se mueve.

Y, a la inversa, toda opresión de la libertad o la falta de amor son antihumanas y, por supuesto, anticristianas, aunque vengan acompañadas de la más intensa religiosidad, como les ocurre a María Sudre (La familia de León Roch), Doña Perfecta, Doña Juana de Casandra, Pantoja de Electra, la familia Lantigua que cerca a Gloria, igual que Juan Crisóstomo a Rosalía, las hermanas Porreño (La fontana de oro), etc. Entonces, lo importante, lo verdaderamente transcendente para Don Benito, padre de todas esas creaturas literarias (¿para él mismo autor también, tal vez?) no es tanto la relación personal con la divinidad (la religión) sino el comportamiento moral de signo evangélico que guía la trama de sus hijos, a partir de la religiosidad personal o al margen de ella; y, junto a esto, desde luego, lo grave es el conflicto moral que les crea su enfrentamiento con la institución religiosa o con los tipos religiosos patológicos.

\footnotetext{
${ }^{11}$ B. Pérez Galdós, Ángel Guerra (Madrid: Alianza Editorial, 1986), 606 (v. p. 608).
} 
Los textos de Don Benito en cuanto a la dimensión religiosa de su pensamiento se sitúan mayoritariamente en este nivel de la ética, coincidente -la mayor parte de las veces- con el Evangelio y los orígenes de la mentalidad cristiana.

Salvador Monsalud asciende -a lo largo de diez largos Episodios- un camino moral que lo llevará a la paz y al estatus bien ganado de una parcela del Reino de Dios. Y Nazarín y Benina y santa Juana de Castilla suben también -por su ética de las bienaventuranzas evangélicas- a los umbrales de la santidad. Algunos de ellos precisamente cuando aciertan a situarse en una paradisiaca comunidad religiosa como la de Pedralves de Halma, la Domus Domini de Ángel Guerra o el asilo de Nuestra Señora de la Indulgencia, de Pedro Minio.

Sintetizo esta dimensión inicial del pensamiento religioso galdosiano en estos postulados:

\section{a) Tensión de la conciencia moral y de la buonhomía}

La tarea permanente (o pendiente) de los personajes galdosianos es formar rectamente su conciencia moral: discernir entre el bien y el mal y llegar a optar por el bien. Ambas tensiones son arduas, a veces extraordinariamente difíciles. Y a Galdós le resulta intolerable el ver que las personas sobreseen su propia conciencia moral mientras generan crueldad y dejan interiormente hundidas a otras. Esto es lo que hacen Juan Santa Cruz en Fortunata y Jacinta, Don Lope, el de Tristana, Pedro Polo en Tormento y bastantes más, generalmente banalizando su tiranía sobre mujeres.

Y por esa misma razón respeta, en cambio, la confesión del infiel Bueno de Guzmán en Lo prohibido y admira la lucha interior de Rosario en Doña Perfecta:

«Dentro de mí una gran culebra me muerde y me envenena el corazón. ¿Qué es esto que siento? ¿Por qué no me matas, Dios mío?... Es espantoso, pero lo confieso, lo confieso a solas, a Dios, que me oye, y lo confesaré ante el sacerdote. Aborrezco a mi madre... Un impulso terrible me arroja de esta casa. Quiero huir, quiero correr fuera de aquí» ${ }^{12}$.

Para esta tarea Galdós piensa que el hombre necesita dos cosas:

$1^{\text {a }}$, una opción por la sinceridad y la verdad, la que expresa el personaje Víctor en el drama La de San Quintin:

\footnotetext{
${ }^{12}$ B. Pérez Galdós, Doña Perfecta (Madrid: Cátedra, 1993), 240.
} 
«(Víctor:) Declaro la guerra a muerte a toda mentira, cualquiera que sea su valor. (Rosario:) ¿Ama usted la verdad? (Víctor:) Sobre todas las cosas. (Rosario:) ¿Y sostiene que la verdad debe imperar siempre? (Víctor:) Siempre. (Rosario:) ¿Aunque ocasione grandes males? (Víctor:) La verdad no puede ocasionar males» ${ }^{13}$.

«Conocerá usted a un hombre muy severo de principios, recto como los caminos de Dios, veraz como el Evangelio». (Se dice de Donoso, único personaje alabado por el autor $)^{14}$ y se rechaza totalmente la actitud que -con ironíaaconseja El Nasiry (falso converso al Islam):

«El cristiano que acá venga y no sepa fingir, o muere o tiene que salir pitando. Se hace aquí fortuna más o menos grande según el grado de simulación que cada uno se traiga para poder vivir entre esta plebe... En mí tienes ejemplo vivo del arte de figurar lo que no es... $\rangle^{15}$.

Y $2^{\mathrm{a}}$, vivir un ideal, un cierto nivel de idealismo elevado (no material ni dominador) como individuo y como grupo.

Uno de los grandes idealistas del mundo galdosiano, Gabriel de Araceli, expresa con claridad esta condición básica de la moral:

"¿Qué es el hombre sin ideal? Nada, absolutamente nada: cosa viva entregada a las eventualidades de los seres extraños, y que depende de todo, menos de sí misma; existencia que, como el vegetal, no puede escoger en la extensión de lo creado el lugar que más le gusta... El hombre sin ideal es como el mendigo cojo que, puesto en medio del camino, implora un día y otro la limosna del pasajero... Todos van y él se queda siempre, pues ni tiene piernas para andar, ni tampoco deseos de ir más lejos» ${ }^{16}$.

A esta perspectiva dedica Galdós tres ensayos importantes para perfilar su pensamiento: Soñemos, alma, soñemos, Guía espiritual de España y La fe nacional.

\footnotetext{
${ }^{13}$ B. Pérez Galdós, La de San Quintín (Madrid: Cátedra, 2002), 168.

${ }^{14}$ B. Pérez Galdós, Torquemada en la cruz (Madrid: Alianza Editorial, 2008), 121.

${ }^{15}$ B. Pérez Galdós, Aita Tettauen (Madrid: Historia 16-Caja Madrid, 1996), 236.

${ }^{16}$ B. Pérez GaLdós, Napoleón en Chamartín (Madrid: Casa Editorial Hernando, 1974), 56.
} 
b) Teología de la justicia

Galdós muestra en todo momento la pasión por la justicia en todos los órdenes de las relaciones humanas; una justicia coherente con las más puras exigencias del Evangelio, plasmada, ante todo, en tres dimensiones:

$1^{\text {a) }}$ La defensa de la libertad y la condena de cualquier forma de sometimiento y esclavitud.

Gritos que aún resuenan reclamando libertad son Electra, Casandra, Victoria, Tristana, Gloria, Doña Perfecta, Rosalía, Tormento..., casi siempre mujeres. La lista queda incompleta, es interminable. La primera condición de la justicia es la liberación de la opresión que padecen muchos de sus personajes precisamente en función de una cultura pseudocristiana. Éste es el sentido que Patricio Sarmiento da a su propia muerte convirtiéndola -a pesar de su locura- en una inmolación por la libertad en nombre de Dios.

«Soledad y yo nos declaramos reos de amor a la libertad» (...) «Señor, tú que me conoces sabes que te adoro... Sabes que la idea de la libertad enviada por ti para que la difundiéramos fue mi norte y mi guía. Sabes que por ella vivo y por ella muero» ${ }^{17}$.

Y con acento parecido, Tristana:

«No sabré amar por obligación; sólo en la libertad comprendo mi fe constante y mi adhesión sin límites. Protesto, me da la gana de protestar contra los hombres, que se han cogido todo el mundo por suyo, y no nos han dejado a nosotras más que las veredas estrechitas por donde ellos no saben andar» ${ }^{18}$.

Es también la consagración creyente a la libertad que hacen de sí mismos dos de los personajes más queridos del autor, Lázaro (La fontana de oro. 1870) y Santiago Íbero (Vergara. 1899), distantes treinta años por su nacimiento:

"Cuando yo no crea en la libertad, no creeré en nada y seré el más despreciable de los hombres. Yo creo en la libertad que está en mi naturaleza, para que la manifieste en los actos particulares de mi vida» ${ }^{19}$. «Íbero, fortalecido por su fe ciega en el ideal de los libres, que creía obra de Dios..., aunque odiaba el fanatismo, era creyente y buen cris-

${ }^{17}$ B. Pérez Galdós, El terror de 1824 (Madrid: Historia 16-Caja Madrid, 1924), 144 (v. p. 202 y 216).

${ }^{18}$ B. Pérez Galdós, Tristana (Madrid: Cátedra, 2010), 206.

${ }^{19}$ B. Pérez Galdós, La fontana de oro (Madrid: Alianza Editorial, 2007), 186. 
tiano; y lejos de ver incompatibilidad entre la libertad y el dogma, teníalos por amigos excelentes $»^{20}$.

$2^{\mathrm{a}}$ ) La opción por los desheredados de este mundo, por la gente baja y empobrecida, por los miserables del realismo francés, por los pequeños y despreciados. Con la consiguiente denuncia radical de la desigualdad distributiva, del funcionamiento de la burguesía improductiva, y de la usura.

Esto es lo que expresa -con sentido de culpa-:

«En ese mundo quiero penetrar, Pastor; a esos abismos quiero descender para conocer por mí misma el sufrimiento de los que nada poseen... Yo estoy preparada; bajo a los infiernos con un entusiasmo, con una ilusión que no puedo explicarte; en este maldito cielo donde me ha encasillado mi destino, me moriría de tristeza si no escapara de él como alma que lleva el Diablo» ${ }^{21}$.

Y esa es la razón de su amor tierno preferente e incondicional a Marianela, al eterno cesante Ramón Villamil (Miau), a Celipín (El doctor Centeno), a Amparo (Tormento), a Fortunata y Mauricia (Fortunata y Jacinta), Isidora y Rufete (La desheredada)... y, su clamor continuo contra el maltrato y desamparo que sufren las mujeres y los menores: Isidora, Tristana, Amparo (Tormento), Fidela (serie Torquemada), Dulcenombre (Ángel Guerra), Benina (a pesar de su señorío espiritual), Marianela, Cadalsito (Miau), el «doctor Centeno»... en las novelas. En los Episodios: Inés ( $1^{\mathrm{a}}$ serie), Sola ( ${ }^{\mathrm{a}}$ serie), Aura ( $3^{\mathrm{a}}$ serie), Mita, Lucila, Teresa Villaescusa y Donata ( $4^{\mathrm{a}}$ serie) y tantas otras. Electra, Bárbara, Victoria, Casandra, Mariucha... en el teatro. ¡Siempre, mayoritariamente, mujeres!

Grito que alcanza en Marianela -con asombrosa naturalidad- el tono más elevado de exigencia, planteando un compromiso de justicia impensable para la acomodada conciencia burguesa de los progresistas siglos XIX, XX y XXI:

«El problema de la orfandad y de la miseria infantil no se resolverá nunca en absoluto, como no se resolverán tampoco sus compañeros los demás problemas sociales; pero habrá un alivio a mal tan grande cuando las costumbres, apoyadas por las leyes..., por las leyes, ya veis que esto no es cosa de juego, establezcan que todo huérfano, cualquiera que sea su origen, tenga derecho a entrar en calidad de hijo adoptivo en la casa de un matrimonio acomodado que carezca de hijos. Ya se

\footnotetext{
${ }^{20}$ B. Pérez Galdós, Vergara (Madrid: Historia 16-Caja Madrid, 1996), 84.

${ }^{21}$ B. Pérez Galdós, Celia en los infiernos (Madrid: Cátedra, 2006), 364-365.
} 
arreglarían las cosas de manera que no hubiera padres sin hijos, ni hijos sin padres $»^{22}$.

Y es también el alegato de Pepe Fajardo en el Episodio O'Donnell:

«La vida que vienes haciendo es enteramente estúpida... Sostengo que no hay derecho a vivir así. Se dice que cada cual hace de su dinero, de su tiempo y de su salud lo que quiere; y yo afirmo que eso no puede ser. En el dinero, en el tiempo y en la salud de cada persona hay una parte que pertenece al conjunto, $\mathrm{y}$ al conjunto no podemos escatimarla. Una parte de nosotros no es nuestra, es de la totalidad, y a la totalidad hay que darla... Tú, Guillermo, eres idiota y criminal, porque gastas todo tu dinero, todo tu tiempo y toda tu salud en no hacer nada que conduzca al bien general» ${ }^{23}$.

Y el del hombre bueno Juan Bou:

«Es cosa que aterra el pensar todo el sudor del pueblo, todos los afanes, todas las vigilias, todos los dolores, hambres y privaciones que representa este lujo superfluo. Eso es: el pobre obrero se deshuesa trabajando para que estos holgazanes se den la buena vida en estos palacios llenos de vicios y crímenes, sí, de crímenes, no me arrepiento de lo dicho. ¡Maldita casta!»» ${ }^{24}$.

A lo largo de la serie de Torquemada y de piezas como Realidad o las parábolas La razón de la sinrazón y El tacaño Salomón (aunque en estas últimas triunfe la justicia) Galdós fustiga el mal endémico de la humanidad: el enriquecimiento por la usura (uno de los pecados más viejos del Antiguo Testamento).

Al juzgar estas situaciones Galdós hace hablar a los santos padres de los primeros siglos de la Iglesia en una de sus últimas novelas El caballero encantado citando expresamente textos de los mismos (quizás demasiado silenciados $)^{25}$.

${ }^{22}$ B. Pérez Galdós, Marianela (Madrid: Cátedra, 2005), 144-145.

${ }^{23}$ B. Pérez Galdós, O'Donnell (Madrid: Historia 16-Caja Madrid, 1995), 49-52.

${ }^{24}$ Pérez, La desheredada..., 381.

${ }^{25}$ «Hijos míos, conciudadanos: no porque las diga yo, sino porque las dijo San Agustín, grabad en vuestra mente estas verdades: "Cualquiera que posea la tierra es infiel a la ley de Jesucristo..." retened también estas otras de San Ambrosio: "La tierra ha sido dada en común a todos los hombres. Nadie puede llamarse propietario de lo que queda después de haber satisfecho sus necesidades naturales". Más fuerte estuvo San Gregorio -afirmó el cura disparando este cañonazo-: "Hombre codicioso, devuelve a tu hermano lo que le has arrebatado injustamente". Y el sabio Don Quiboro prosiguió 
$3^{\mathrm{a}}$ ) La lógica de la justicia llevará a Galdós a convertir su creación también en una condena radical, sin condiciones atemperantes, de toda forma de violencia, fundamentalmente de la guerra y de la pena de muerte cada vez que en las tramas noveladas surgen estos hechos, como sucede en bastantes Episodios: en las conversaciones de José Fago con el ermitaño (Zumalacárregui) y de Santiuste con los capellanes castrenses (Aita Tettauen) o en El equipaje del rey José (en palabras de uno de los legionarios napoleónicos):

«Óiganme, señores míos, y si quieren hacerme caso, bien, y si no, también. Yo les digo que la guerra es pecado, el pecado mayor que se puede cometer, y que el lugar más terrible de los infiernos está señalado para los generales que mandan tropas, para los armeros que fabrican espadas o fusiles, y para todos los que llevan a los hombres a ese matadero con reglas. La gloria militar es la aureola de fuego con que el demonio adorna su cabeza... Yo rezo todos los días por que los militares abran los ojos a la verdad, y abominen de las matanzas $»^{26}$.

Y en las ejecuciones del militar Montes de Oca, o la del Cura Vinuesa, y en las campañas carlistas, en expresión del personaje Juanito Santiuste:

«Sentí aflicción hondísima, terror, vértigo, cual si me viera al borde de un abismo negro y sin fondo. Quise huir, mas ya no era posible. La multitud me enclavijaba con su cuerpo macizo. En mi retina se estampó la imagen del reo, calificado de traidor... No quería yo ver tal ultraje a la Naturaleza. Mi temblor y el temblor de todos anunciaban un cataclismo del mundo moral... El murmullo de la multitud acarició el cadáver como una honda de gemidos de responso. ¡Oh iniquidad, baldón de la naturaleza, bofetada y palos en la misma persona de la Divinidad! ¡A las tres de la tarde, en un espléndido día de abril, cuando el sol alegra los campos, y la tierra fecunda echa de sí para regalo del hombre toda la magnificencia de flores y frutos, la ley nos ofrece su auto siniestro de la Fe jurídica y militar, remedo de los sacrificios idolátricos! ¡Y se llama ley lo que es contrario al sentimiento y a la razón ley, la violación salvaje del principio cristiano! ¿En qué te diferencias, ley matadora, de los criminales que matan?... En que has

así: "Amigos convecinos, hermanos en el martirio de Boñices, oíd esto otro de San Gregorio Nacianceno: 'El que pretenda hacerse dueño de todo, poseerlo por entero, y excluir a sus semejantes de la tercera o de la cuarta parte, no es un hermano, sino un tirano, un bárbaro cruel, o, por mejor decir, una bestia feroz"”». (B. Pérez Galdós, El caballero encantado (Madrid: Cátedra, 2000), 251-252).

${ }^{26}$ B. Pérez Galdós, Zumalacárregui (Madrid: Historia 16-Caja Madrid, 1994), 86-87. 
sabido cohonestarla con formas hipócritas de moral falsa y de religión contrahecha $»^{27}$.

La violencia desvirtúa, pues, radicalmente - para el escritor- cualquier intento de justificación religiosa de la misma. Él asiste horrorizado a los demasiado numerosos «ajusticiamientos» bendecidos por eclesiásticos a lo largo de los Episodios Nacionales, entre otros, en La campaña del Maestrazgo.

\section{c) Teología del amor cristiano}

Sin duda, donde las obras de Galdós alcanzan los niveles más altos de espiritualidad, de una espiritualidad expresiva de la conciencia moral influida por los postulados evangélicos esenciales es a propósito del amor, un amor que se convierte casi espontáneamente en caridad heroica; es decir, en ternura y en donación absolutamente generosa de la vida, hasta límites insospechados, fecundado con naturalidad por la fe cristiana.

Como dice muy bien Joseph Jelelaty: «Hablar del amor en la obra novelística de Galdós es uno de los problemas más difíciles, dada la frecuencia con que encontramos en ella el amor» (traducción personal) ${ }^{28}$.

Nazarín, Benina, Leré, Inés, Ángel Guerra, Catalina de Artal, Soledad Gil de la Cuadra, Benigno Cordero..., el médico Guillermo, las monjas del Asilo de la Misericordia, Juana de Castilla, Sor Simona, Marianela... llegan con extraordinaria rapidez a ese nivel, hacia el que caminan juntos (aunque vayan algo más lentos) Clara y Lázaro, Rosario y Pepe Rey, Gloria y Daniel, Rosalía y Horacio Reynolds en las novelas; Inés y Gabriel, Agustín y Mariquilla Candiola, Soledad y Salvador, Fernando Calpena y Demetria, Santiago Íbero y Gracia, Leo y Mita en los Episodios; Electra y Máximo, Mariucha y León... entre otros.

Todos a través de enormes renuncias sólo espiritualmente justificadas. Un amor al que no pueden llegar María Sudre y León Roch obstaculizados por la religión.

El concepto de amor y el ejercicio del amor (de toda clase de amores) viene informado frecuentemente en la obra galdosiana por una alusión expresa a Dios, a un Dios que asume y potencia los más altos valores de las relaciones interhumanas.

Ese amor de caridad evangélica está, para Galdós, por encima de cualquier religión. En La primera República se dice del diputado Estanislao Figueras:

${ }^{27}$ B. Pérez Galdós, Carlos VI en La Rápita, (Madrid: Historia 16-Caja Madrid, 1995), 177-178.

${ }^{28}$ J. Jelelaty, "L'amour dans l'oeuvre Romanesque de Galdós", Letras de Deusto, 8, vol. 4 (1974), 61. 
«Es el hombre más generoso y bueno del mundo. En él no se admira tan solo la virtud pasiva que consiste en no hacer el mal. En su corazón arde el sentimiento de caridad en su grado más efusivo. No acude a él ningún necesitado que no halle consuelo y socorro... En los casos difíciles (de los perseguidos por la justicia) habla con los jueces, revuelve toda la Curia, y no descansa hasta conseguir la libertad del preso. Si para los extraños es misericordioso, para los amigos no tiene límite su bondad. Practica el principio cristiano en toda su pureza, desentendiéndose en absoluto de la liturgia (del cumplimiento religioso en el templo; por lo que resulta, según el criterio de los neoconservadores), un ángel impío, un santo anticlerical» ${ }^{29}$.

El amor en que piensa el autor es absoluto: llega a definir a la persona y está abierto a todos los seres, incluso a aquellos a quienes parece imposible amar. Es el que tiene Inés, heroína de la primera serie de Episodios al indeseable Luis de Santorcaz, el padre que le ha amargado la vida, dando a la joven una entidad divina.

«¿Pues qué he hecho que no sea natural? -pregunta Inés-. Y Gabriel le responde: ¿Que qué has hecho? Has hecho lo que yo no esperaba ni adivinaba, aunque siempre te tuve por la misma bondad: has amado a ese infeliz, el más infeliz de los hombres, y este prodigio que ahora, después de hecho, me parece natural, antes me parecía una aberración y un imposible. Tú tienes el instinto de lo divino... Tú realizas con la sencillez propia de Dios las más grandes cosas... Tu corazón no sabe sino amar» ${ }^{30}$.

A una altura semejante han llegado Marianela al final de su corta vida. De quien dice el autor:

«En su rudeza pudo observar que el conflicto en que estaba su alma provenía de no poder aborrecer a nadie. Por el contrario, érale forzoso amar a todos, al amigo y al enemigo; y así como los abrojos se trocaban en flores bajo la mano milagrosa de una mártir cristiana, la Nela veía que sus celos y su despecho se convertían graciosamente en admiración y gratitud $»^{31}$.

Y Benigno Cordero, el hombre bueno muy entrado en años que soñaba con casarse con Sola:

\footnotetext{
${ }^{29}$ Pérez, La primera..., 105-106

${ }^{30}$ B. Pérez Galdós, La batalla de los Arapiles (Madrid: Alianza Editorial, 1998), 183-184.

${ }^{31}$ Pérez, Marianela ..., 192.
} 
«He creído amarte mejor y servirte mejor, y amar y servir mejor a Dios, dándome a ti por padre antes que por esposo... Y aún me queda otra cosa mejor que decirte. Esto que he hecho sería incompleto, muy incompleto, si quedara así... Al hacerte mi hija quiero llenar el vacío que hay en tu existencia y poner a tus sentimientos la corona que has ganado; quiero llenar de felicidad hasta los bordes ese vaso de tu vida...; quiero casarte con el hombre que amas, con ese de quien yo puedo asegurar que te merece $\rangle^{32}$.

La tesis fundamental de Galdós es que sólo el amor redime y salva a la persona.

Es lo que ilustra, por ejemplo, el drama Amor y ciencia refiriéndose al médico Guillermo cuando recoge de la calle un bebé abandonado: «Lo mismo fue tenerle entre mis manos, que sentirme inundado de piedad y disiparse, como de milagro, todo aquel furor de suicida que llevaba al salir de mi casa» ${ }^{33}$. $\mathrm{O}$ la visión que tiene Tito del amor de Floriana a los pequeños, durante su viaje iniciático:

«En derredor de la divina maestra, un enjambre de pequeñuelos de ambos sexos recibía las primeras migajas del pan de la educación... A unos les corregía con gracejo, a otros con besos los estimulaba; a los más chiquitines les sentaba sobre sus rodillas... Había tan sólo cariño, halagos, persuasión y un extraordinario poder espiritual... Un sacerdote santo dando la comunión a los fieles, en las catacumbas, no me hubiese inspirado mayor respeto... Besos, cariños, alegría, risas que eran como un himno a la Enseñanza, y desfiló aleteando a infantil bandada $»^{34}$.

Y la experiencia transcendente de Pepe Fajardo ante el amor que recibe de Antonia: "Yo no era digno de un cariño tan hondo, tan puro, tan superior a todo interés y a las conveniencias humanas $»^{35}$. «El amor es estímulo, fuerza, savia..., es - ¿qué se yo? - todo lo bueno, lo que alienta a las creaturas y las hace dignas de Dios ${ }^{36}$.

${ }^{32}$ B. Pérez Galdós, Un faccioso más y algunos frailes menos (Madrid: Historia 16-Altorrey, 1994), 134-135.

${ }^{33}$ B. Pérez Galdós, Amor y ciencia. Obras Completas (Madrid: Aguilar), t. IV, 631-632.

${ }^{34}$ B. Pérez Galdós, La primera República (Madrid: Historia 16-Caja Madrid, 1995), 204-205.

${ }^{35}$ B. Pérez Galdós, Tormentas del 48 (Madrid: Historia 16-Caja Madrid, 1995), 175.

${ }^{36}$ B. Pérez Galdós, Alma y vida (Salamanca: Clásicos Almar, 1987), 229. 
d) Recuperación de una idea saludable de Dios frente a un Dios hostil

Dios (la palabra y la idea) está presente en todo el mundo galdosiano, casi siempre intentando recuperar una concepción de la divinidad que sea justa y digna para el hombre; denunciando las patologías incubadas a costa de lo religioso (por ejemplo, las que dimanan del carlismo, de la suma de intereses privados inconfesables, o de una pseudomística religiosa).

Para el autor la conciencia moral y todo el comportamiento ético (al que nos hemos aproximado) son realidades unidas estrechamente a la propia concepción religiosa. Una idea inhumana de Dios conduce -para él- a conductas malsanas (de fanatismo absorbente, de misticismo patológico, de intransigencia e intolerancia en las relaciones a las que se tiene acceso) e incluso aberrantes que pueden culminar en la muerte: en el asesinato o el suicidio y en la locura.

Esto es lo que sucede en las novelas básicas de la primera época: El audaz, La fontana de oro y sobre todo en la trilogía Doña Perfecta, Gloria y Rosalía; quizás también en el relato breve La sombra.

En este sentido, el autor, cuando condena tales confesiones religiosas y conductas consecuentes, está proponiendo otra idea sana -saludable y valiosa- de Dios, sea ésta cristiana (consciente de una divinidad amable, participativa y respetuosa de la dignidad del ser humano) o simplemente natural y emotiva como la que acompaña, por ejemplo, a Marianela, idea que, sin embargo, es capaz de mantenerla en las cimas del amor aún en los momentos de mortal decaimiento. Porque, para Galdós, la idea correcta de Dios es psicológicamente liberadora. Así lo expresan Nazarín hablando con su compañero de prisión, El sacrílego, y el desengañado Maximiliano Rubín (al que Fortunata no puede amar):

«No hay delito que sea bastante grande para medirse con la misericordia de Dios... Cuando esto decían, penetraba por las altas rejas la luz del alba $»^{37}$.

«Me parecía a mí mentira que yo había de ver apagarse en mí la sed de venganza, y el odio que me embruteció. Y, sin embargo, el tiempo, la abstracción, el pensar en el conjunto de la vida y en lo grande de sus fines me han puesto como estoy ahora... ¡Dichoso el que sabe elevarse sobre las pasiones de momento y atemperar su alma en las verdades eternas! En este bulle-bulle de las pasiones de los hombres del día, llega uno a olvidarse de que vivimos para perdonar las ofensas y hacer bien a los que nos han hecho mal, -y concluye- Entonces no veía a Dios en mí; ahora sí que le veo»» ${ }^{38}$.

${ }^{37}$ Pérez, Ángel..., vol. I, 14.

${ }^{38}$ B. Pérez Galdós, Fortunata y Jacinta (Madrid: Cátedra, 1999), vol. II, 137-138. 
En consecuencia, toda la obra de Galdós es un alegato tremendo contra la idea religiosa que impone la autodestrucción de la persona por el sacrificio de sí. Ese es el grito de Daniel Morton en Gloria. Y así deben interpretarse Electra, Rosalía y la impotencia de Bárbara y de Victoria, así como la huida de Santiago Íbero a un convento.

Muy al contrario, siguiendo de cerca la teología joánica («Quien ama ve a Dios»), sólo el amor es el acceso a la intuición del Dios de Jesucristo. Es el testimonio de Pepe, mirando a Rosario:

«Tú te empeñas en que no vales nada -continuó Pepe-, y eres una maravilla. Tienes la cualidad admirable de estar a todas horas proyectando sobre cuanto te rodea la divina luz de tu alma. Desde que se te ve, desde que se te mira, los nobles sentimientos y la pureza de tu corazón se manifiestan. Viéndote se ve una vida celeste que por descuido de Dios está en la tierra $»^{39}$.

El de Gabriel, extasiado ante Inés:

«Inés, tú eres una criatura superior -afirmé con verdadero entusiasmo-. Tú tienes en tu alma mayor porción de aliento divino que los demás. Amas a tus enemigos, a tus más crueles enemigos...

Tú tienes el instinto de lo divino y yo no; tú realizas con la sencillez propia de Dios las más grandes cosas.

Ambos nos miramos. Un cielo lleno de luz divina y de inexplicable música de ángeles flotaba entre uno y otro semblante... Si es posible ver a Dios, yo lo veía, yo» ${ }^{40}$.

O el de Salvador Monsalud ante Sola: «Eres para nosotros la prueba viva que Dios da de su bondad a las criaturas que no quiere abandonar» ${ }^{41}$.

Las cuatro dimensiones brevísimamente aludidas constituyen, sin duda, la temática primordial del pensamiento teológico de Don Benito. Digo teológico porque en esta prioridad existe ya una coincidencia fundamental con la perspectiva del Evangelio y del Nuevo Testamento que dice en la carta de Santiago: «La religión pura e intachable ante Dios Padre es ésta: asistir a los huérfanos y a las viudas en su tribulación y conservarse incontaminados del mundo» (St 1,27). Es decir, nos hallamos enteramente en el terreno de la teología cristiana.

\footnotetext{
${ }^{39}$ B. Pérez Galdós, Doña Perfecta ..., 118.

${ }^{40}$ B. Pérez Galdós, Batalla de los Arapiles, caps. XXVII y XXXVIII.

${ }^{41}$ B. Pérez Galdós, Siete de julio, cap. II.
} 
2.2. Temas cristológicos y eclesiológicos en la visión galdosiana del hecho cristiano

El pensamiento teológico de Galdós referido a la temática específicamente religioso cristiana se halla, desde luego, menos desarrollado que el de la moral evangélica. No obstante, brilla a mucha altura en cuanto a su claridad, fuerza y amplitud de asuntos. De forma que, hecho el balance a través de toda su creación literaria, me parece que se puede hablar de una auténtica teología sobre Jesucristo, sobre el cauce de la fe cristiana y sobre la Iglesia y sus ministerios. El carácter alternativo de su pensamiento se refiere, sobre todo, a la visión de la Iglesia y del quehacer eclesial.

La mayor parte de esta teología está diseminada, es cierto, a través de obras que expresan con espontaneidad juicios y comportamientos de los personajes que de manera habitual u ocasional entran en esta temática desde la trama de su existencia personal. Pero en varios casos ésta se desarrolla en obras estructuradas en función del análisis del hecho cristiano y del hecho eclesial, como ocurre especialmente en Nazarín, Ángel Guerra y Halma, Misericordia, Doña Perfecta, Rosalía, Gloria, La familia de León Roch, Torquemada y San Pedro, Electra y Casandra.

\section{a) Jesucristo y el concepto de cristianismo}

Galdós hace la pregunta formal sobre Jesús, la misma que en el Evangelio según Juan le hace el sumo pontífice: ¿Eres tú el Mesías esperado? Y contesta personalmente de forma afirmativa -de manera rotunda- desde las palabras y el juicio de sus personajes más emblemáticos: «Sí, en efecto: tú lo dices». Él mismo se introduce en la novela, al final de Gloria y hace esta confesión de fe en una simbólica trasposición de los dos niños, el pequeño nacido de Gloria y Daniel (del mundo cristiano y del mundo judío) y el hijo de María, José y el Espíritu de Dios:

«Un precioso niño jugaba en el jardín de Lantigua. Era y es la imagen viva de aquel chicuelo divino, cuyos ojos, tan lindos como inteligentes, miraron con amor al mundo antes de reformarlo. Diríase de él que no nació de madre, sino por milagro del arte y de la fe, recibiendo cuerpo y vida de la ardiente inspiración de Murillo.

En Ficóbriga le llamaban y le llaman "el Nazarenito"...

Tú, precioso y activo niño Jesús, estás llamado sin duda a intentarlo; tú, que naciste del conflicto, y eres la personificación más hermosa de la humanidad emancipada de los antagonismos religiosos por virtud del amor; tú, que en una sola persona llevas sangre de enemigas razas, 
y eres el símbolo en que se han fundido dos conciencias, harás sin duda algo grande. Hoy juegas y ríes e ignoras; pero tú tendrás treinta y tres años, y entonces quizá tu historia sea digna de ser contada, como lo fue la de tus padres» (Final de Gloria) ${ }^{42}$.

La misma fe que pone en labios de la genial Teresa Villaescusa, mujer de Santiago Íbero hijo, en el Episodio O'Donnell:

«Mientras lavaba y fregoteaba, primero mi rostro, después mi camisa, yo, como todo el que está muy alegre, cantaba y rezaba, que rezo y canto era todo lo que salía de mi boca... recitaba con amor y fe aquel pasaje del advenimiento del Redentor: "El que había de venir, viene; el que había de llegar, llega; pero no viene ni en el seno de la sonrosada nube ni en el de las estrellas, sino manso y humilde en el seno de la pobreza y de la desgracia. No viene acompañado de numeroso ejército, sino de su bendita palabra y de su eterno amor; no viene seguido de esclavos, sino ansioso de acabar con toda esclavitud...; no viene a levantar pueblo contra pueblo, ni una raza sobre los huesos de otra raza, sino a estrechar contra su pecho y a bendecir con infinito amor de su corazón todos los pueblos y todas las razas..." "Él, causa de toda vida, autor de toda existencia, se despoja de su vida, de su existencia, por la salud y la libertad de los hombres en el altar sublime del Calvario"» ${ }^{43}$.

La figura de Jesús de Nazaret le es real y transcendente en su significación humana y divina, así como la de su madre María. Juanito Santiuste, en diálogo ecuménico en Aita Tettauen, otorga al cristianismo la función esencial de llevar el mundo a la unidad soñada, a la convergencia de todos los seres, pueblos y razas. Al mismo tiempo que emerge una dialéctica de proximidad y de trascendencia, incluso de resurrección, como en la muerte de Ángel Guerra, al final de la obra.

«En lo esencial -dice Guerra-, quiero parecerme a los primitivos fundadores, y seguir fielmente la doctrina pura de Cristo. Amparar al desvalido, sea quien fuere; hacer bien a nuestros enemigos; emplear siempre el cariño y la persuasión, nunca la violencia; practicar las obras de misericordia en espíritu y en letra, sin distingos ni atenuaciones, y, por fin, reducir el culto a las formas más sencillas dentro de la rúbrica; tal es mi idea. Soy un pecador indigno; espero redimirme con la oración,

\footnotetext{
${ }^{42}$ Pérez, Gloria..., 471.

${ }^{43}$ Pérez, O’Donnell..., 172-173.
} 
con este trabajo en pro de la humanidad y en nombre de Cristo Nuestro Señor» ${ }^{44}$.

Este proyecto de cristianismo es el que encarna la ex reina Juana de Castilla, hija del emperador, a la que Galdós canoniza por decreto propio.

De modo particular, el misterio saludable de la entrega voluntaria de Jesús a la Pasión y Muerte, y el Misterio creyente de su Resurrección surgen repetidas veces en obras simbólicas tan distintas, como el drama Alceste y el final de las novelas Nazarín y Ángel Guerra.

El sentido del cristianismo aparece desarrollado -a modo de síntesis- en la encendida apología que hace el joven filósofo Santiuste (trasunto del autor) dialogando con el judío amigo Baruc; texto en el que parece escapársele a Galdós su fe firme en la figura de Cristo y en la obra original del cristianismo.

«Hizo Santiuste la apología del Cristianismo en variedad de tonos, descendiendo del sublime al patético; ensalzó la intensa ternura de la predicación de Cristo, por la cual éste penetró en las entrañas de la Humanidad, conquistándola y haciéndola suya para siempre; marcó luego la obra inmensa de los apóstoles, para afianzar la doctrina del Redentor sobre las ruinas del Imperio, y la siguiente labor de los Padres para fijar en dogmas inmutables todo el organismo de la Hermandad Cristiana; describió la tenaz gestación de la Iglesia para formarse, para edificar su imperio militante y docente, y sostenerlo con robusta trabazón arquitectónica en el curso de los siglos. ¿Cuándo había visto la Humanidad obra tan grande y sintética, ni organización tan poderosa? La doctrina de Cristo había venido a ser la única normalidad espiritual de los pueblos civilizados... Declaró Santiuste con emoción y solemnidad que, de las confesiones cristianas, prefería la católica porque en ella había nacido y porque era la más bella, la más latina, en el sentido etnográfico, y la que a su parecer responde mejor a los fines humanos» ${ }^{45}$.

El texto merecería un análisis detenido.

\section{b) La Iglesia, la institución eclesial y su reforma}

¿Qué es la Iglesia para Galdós, qué debiera ser? Sin la menor duda: una casa acogedora, un hospital de campaña en donde no se pregunta la procedencia ni la identidad de los heridos, tal como dice el Papa Francisco.

\footnotetext{
${ }^{44}$ Pérez, Ángel Guerra..., vol. II, 527.

${ }^{45}$ Pérez, Aita ..., 219
} 
«El tratamiento del cariño, de la confraternidad, de la exhortación cristiana, sin hierros, sin violencia de ninguna clase... El pecador que aquí venga no podrá menos de sentirse afectado por el ambiente de paz que ha de respirar... Viene a ser esto la casa temporal de Dios, donde se entra por amor, se reside por fe, y se sale franqueando una puerta en cuyo frontón esta la Esperanza» (Estatuto de la fundación «Domus Domini» de Ángel Guerra) ${ }^{46}$.

«Mis ojos llorando, mis dedos soltando pitillos, así me ha ido la vida..., vida de perros... No respiré, no viví hasta que las olas de Dios, pum, me trujeron (sic) a esta playa» (una secular comunidad eclesial) «Si, señora. Esto es la gloria $»^{47}$,

confirman Pascasia y Ladislada, personajes de la residencia de Nuestra Señora de la Indulgencia.

Es decir, una aproximación del Reino de Dios, precisamente por la estructura de pequeñas comunidades fraternas como las de Predalves de Catalina de Artal en Halma, la Domus Domini en el cigarral de Ángel Guerra o la de las residencias de Amor y Ciencia y de Pedro Minio. Galdós sueña en esta utopía de una Iglesia (más ecuménica que la Iglesia católica experimentada por él) que sea un espacio del Reino de Dios para el mundo.

Curiosamente es Buenaventura Lantigua (Gloria) quien, con perspectiva ecuménica, expone al liberal judío Daniel el credo de una Iglesia abierta, liberal y fiel a sus orígenes, servidora del desarrollo de la Humanidad.

«Yo creo que la fe religiosa, tal como la han entendido nuestros padres, pierde terreno de día en día, y que tarde o temprano todos los cultos positivos tendrán que perder su vigor presente. Yo creo que los hombres buenos y caritativos pueden salvarse, y se salvarán fácilmente, cualquiera que sea su religión. Creo que muchas cosas establecidas por la Iglesia, lejos de acrecentar la fe, la disminuyen, y que, en todas las religiones, y principalmente en la nuestra, sobran reglas, disposiciones prácticas. Creo que los cultos subsistirán mejor si volvieran a la sencillez primitiva. Creo que, si los poderes religiosos se empeñan en acrecentar demasiado su influencia, la crítica acabará con ellos. Creo que la conciliación entre la filosofía y la fe es posible, y que si no es posible vendrá el caos $»^{48}$.

\footnotetext{
${ }^{46}$ Pérez, Ángel..., 526.

${ }^{47}$ Pérez, Pedro Minio (Madrid: Aguilar), 643 y 659.

${ }^{48}$ Pérez, Gloria..., 307.
} 
Sin embargo, desde El audaz. Memorias de un radical de antaño hasta Tormento, El abuelo, etc, Galdós lamenta que la experiencia de la Iglesia no haya sido ésa. Entre otros, dos textos fundamentales de penosa actualidad en expresión de Amparo (Tormento) y de la excelente religiosa que ha acogido a Electra:

«Todo recuerdo de cosas eclesiásticas, toda alusión o referencia a ellas, la hacían temblar con escalofríos, como si le pusieran un cilicio de hierro. Entonces era cuando su conciencia se alborotaba más, cuando su sangre hervía y cuando el corazón parecía subírsele a la garganta, cortándole el aliento ${ }^{49}$

«Ven. A la Iglesia, no»-le dice la monja superiora del convento, con un doble sentido, y Electra corrobora:- «Quiero respirar... Quiero vivir» $~^{50}$.

Podemos afirmar sin lugar a duda también que la obra entera de Galdós entra de lleno en el tema siempre pendiente de la reforma de la Iglesia, en el sentido de un retorno de la misma a sus orígenes apostólicos, a la ternura, y, por tanto, de una liberación o aligeramiento de las estructuras que la falsean y que, a la altura del siglo XIX y del XX, le daban una imagen rígida, fuertemente institucional, indebida a su ser original cálido, familiar y profético. Galdós se muestra radicalmente crítico con los postulados del Concilio Vaticano I en cuanto al funcionamiento eclesiástico y papal (Pío IX y Syllabus); su pensamiento se abre no sólo al futuro Concilio Vaticano II sino también a un hipotético Vaticano III que fuera mucho más en la dirección autorrevisionista y de compenetración con los problemas del mundo contemporáneo.

Por eso, como quien atisba un rayo de luz esperanzadora, refiriéndose a la innovadora encíclica de León XIII Immortale Dei, Galdós escribe:

«Lo más reciente y lo más notable de que puedo hablar hoy, es la Encíclica de Su Santidad... Este documento se distingue por lo templado y conciliador de su tono, que contrasta con el violentísimo y antievangélico de la prensa ultramontana de todos los países. La misma cátedra de San Pedro no ha hablado siempre un lenguaje tan moderado como el presente, lo cual hace creer a muchos que se acercan tiempos de reconciliación. León XIII es hombre de gran entendimiento y no puede llevar a la Iglesia a un divorcio absoluto de la sociedad moderna» ${ }^{51}$.

\footnotetext{
${ }^{49}$ B. Pérez Galdós, Tormento (Madrid: Alianza Editorial, 2008), 125.

${ }^{50}$ B. Pérez Galdós, Electra (Madrid: Cátedra), 338.

${ }^{51}$ B. Pérez Galdós, art. en "Escritos inéditos". Citado por Luis Nos Muro en "El otroísmo como religión”, Religión y cultura, LVI, 2010, 740.
} 
En síntesis, su visión de la Iglesia, especialmente de la católica (aunque no sólo de ésta), se podría resumir en estos puntos que profesan con altura de pensamiento algunos de sus personajes queridos y sufrientes, como Pepe Rey, León Roch, Daniel Morton, Horacio Reynolds, Máximo, la ex reina Juana de Castilla, los presbíteros Gamborena, Nazarín, Manuel Florez, Juan Casado, los obispos Paya y Benavides; pensamiento que en ocasiones expresa el mismo autor (en las obras formales y en artículos y ensayos):

- una Iglesia que sea fiel a la simplicidad evangélica,

- abierta y en comunión con las demás confesiones y religiones (especialmente con la judía y la musulmana), incluso caminando hacia una religión universal,

- exenta del poder clerical,

- exenta de poder temporal (sin Estados Pontificios) e independiente de los poderes temporales,

- basada en la configuración de pequeñas comunidades heterogéneas signos del Reino de Dios; no precisamente en comunidades de religiosos,

- cercana a los pobres y servidora de ellos,

- dotada de una liturgia sencilla y bella, aunque solemne y popular, con un ministerio pastoral evangélico,

- y en diálogo permanente y cordial -incluida la humildad- con todas las culturas.

En cuanto a esta reforma de la Iglesia Galdós se declara a favor de las tesis erasmistas, cercanas a la Reforma protestante, más que a la Contrarreforma católica, haciendo comulgar con ellas al mismo San Francisco de Borja en el drama Santa Juana de Castilla, de indudable fondo eclesiológico.

\section{c) El presbiterado cristiano}

Es difícil hallar una obra formal de la producción galdosiana donde no salgan presbíteros (sacerdotes) del clero secular (diocesanos) o del clero religioso; además de un buen número de monjas o religiosas de clausura. Obviamente estos personajes entran en el mundo del autor porque pueblan la sociedad que lo contorna; pero su presencia viene siempre acompañada de un juicio crítico, desfavorable las más de las veces y favorable no pocas. Lo que significa que se trata de un asunto que le preocupa y que no queda resuelto ideológicamente con una postura simplista anticlerical.

En realidad, Galdós no cuestiona la existencia misma del clero; lo que condena es el comportamiento negativo y exasperante de una mayoría de eclesiásticos: el comportamiento depravado (de los sacerdotes Pedro Polo, el arcipreste Juan Hondón...), falso (de Don Inocencio, Don Hilario...), militarista (el de Fago, Lorente, Llangostera...), guerrillero o anarquista (Mosén Antón, 
Vinuesa...), fanático e imperativo (del P. Paoletti y Gonzalo) o simplón, epicúreo y frustrante (de religiosos como Alelí, o Salmón, Entrambasaguas y tantos otros). Y lo que exalta es el tipo de presbíteros encabezado por Nazarín, Gamborena, Nones, Florez, etc.

Es decir, está proponiendo -sobre este asunto- la reforma radical del clero en el sentido más espiritual y más humano, planteamiento que no difiere de las perspectivas pontificias y que parece bastarle; apuntando -sólo de pasada- al sin sentido de la misma institución eclesiástica (el clero) en cuanto tal.

Por sus páginas discurre un repertorio demasiado numeroso de clérigos indignos a causa de su poder temporal y de sus costumbres inmorales; con frecuencia, de conducta cruel o violenta respecto a personas indefensas o a enemigos políticos (encuadrados, sobre todo, en las guerras de la Independencia o carlistas).

«Todos ustedes son holgazanes, glotones, sibaritas, dueños de la mitad del territorio, disolutos, hipócritas: ¿decir esto es blasfemar? ¿Quién ofende a Dios, ustedes que son como son, o yo que lo digo?» Y más adelante: «No digo que no haya excepciones y que algunos entre ellos no sean modestos y sabios; pero, en general, son soberbios, ignorantes, lascivos, pérfidos y glotones. La religión en ellos no es más que una mercancía y Dios un pretexto para dominar el mundo» $»^{52}$.

Sin embargo, aun en estos casos, lo que interesa analizar al autor es la tensión dramática que acompaña a tales personajes, sin duda la psicología dañada que los define; es decir, el problema interior, a veces insoluble, que les supone llevar a cuestas una identidad o una vocación que no les pertenece. El caso más agudo es, sin duda, el del carlista sacerdote José Fago mimetizándose con la figura noble del general Zumalacárregui (en el Episodio de este nombre). Pero podría ser también el de Pedro Polo (El doctor Centeno y Tormento).

Frente a esa amplia tipología clerical negativa, la que ha dado pie a hablar con ligereza del anticlericalismo de Galdós, Don Benito (a lo largo de los tres géneros de su literatura) propone con detenimiento -y ofreciéndoles todo su apoyo- dieciséis eclesiásticos que dignifican extraordinariamente el ministerio presbiteral y que entran de manera muy positiva en el juego de una sociedad más humana y de una religiosidad cristiana más justa.

Es precisamente un presbítero anglicano (cercano al catolicismo) quien expresa el análisis más lúcido de la figura del pastor cristiano de las iglesias.

${ }^{52}$ B. Pérez Galdós, El audaz. Historia de un radical de antaño (Madrid: Ed. Hernando, 1982), 22 (v. p. 69). 
«Hermosa y santa profesión es la del sacerdocio en todas las religiones; pero también la más difícil, la que exige mayor fortaleza de ánimo, mayores virtudes y una abnegación sin límites. Los que la adoptan sin suficiente reflexión y arrastrados por impresiones pasajeras, algún día sienten los inconvenientes de su precipitación y ceguera, y entonces... ¡ya es tarde! (...) Este ministerio exige el recogimiento, la calma, la prudencia, la humildad; exige que el amor propio esté atado con cien cadenas, la conciencia siempre alerta... Bien practicado, el sacerdocio eleva al hombre a la mayor perfección posible dentro de su naturaleza ${ }^{53}$.

Pero el primero de todos los presbíteros galdosianos es, sin la menor duda, el santo quijotesco Don Nazario Zaharín, protagonista de dos novelas (Nazarín y Halma), que merece un estudio no fácil (por la riqueza de factores psicológicos, literarios y evangélicos que concurren en él). Junto a él hay que situar a Horacio Reynolds, Manuel Florez, Gamborena, Nones, Juan Casado, Tomé, Narciso Vidaurre, Don Matías, Don Rafael (de Mariucha), Muñoz Torrero, incluso Pepe Hillo, el duende benéfico de Fernando Calpena, los obispos justos y de índole liberal Paya, de Cuenca y Benavides, de Zaragoza, etc. Juntándolos por recurso literario nos encontramos con un perfil del presbítero cristiano perfectamente diseñado conforme a la mejor teología del orden presbiteral.

Y quizás no hay en toda nuestra literatura un elogio mayor y más íntimo de la actuación de un presbítero, humilde párroco de pueblo, humano, ilustrado, santo y excelente padre, como el que hace Fernando Calpena, protagonista de la tercera serie de Episodios, abandonado de sus progenitores, de Don Narciso Vidaurre:

«Los primeros recuerdos de mi infancia se refieren a Vera, y a la casa del cura de aquel pueblo... No tenía yo dos años cuando éste me llevó consigo, y ya no me separé de él hasta su muerte, ocurrida el año 32. Llamábale yo padrino, y él a mí ahijado y a veces hijo. Era el hombre más excelente que usted puede imaginarse, sin tacha como sacerdote, verdadero pastor de sus feligreses, tan caritativo, que todo lo suyo era de los pobres; entendido en mil cosas, principalmente en agricultura, en astronomía empírica y en humanidades, gran latino, tan modesto en sus hábitos y tan apegado a la humilde iglesia en que desempeñaba su ministerio, que rechazó la oferta de una capellanía de Ronvesvalles y del deanato de Pamplona. Para mí, Don Narciso Vidaurre, que así se llamaba, era la primera persona del mundo, y en él se condensaron siempre todos mis afectos de familia, pues él era para mí como padre y maestro. Si no me había dado la vida, me dio la crianza, la educación,

${ }^{53}$ B. Pérez Galdós, Rosalía (Madrid: Cátedra, 1984), 64. 
y me enseñó a ser hombre, infundiéndome la dignidad, la confianza en mí mismo, y preparándome para los mil trabajos de la vida. Desde niño me enseñó todo lo concerniente, en lo moral y en lo social, a personas principales... Su muerte fue para mí un golpe tremendo. Parecíame que se acababa el mundo, la humanidad; que yo me veía condenado a soledad eterna, a un desamparo tristísimo» ${ }^{54}$.

Las figuras presbiterales de Don Nazario (Nazarín), Don Manuel Florez (Halma), Gamborena (Torquemada y San Pedro), el P. Nones (Fortunata y Jacinta, Tormento), Don Narciso (Mendizábal), Tomé (Ángel Guerra), León (Mariucha)... son casi perfectas desde el punto de vista teológico y pastoral.

Así, pues, Galdós no es en modo alguno un anticlerical estereotipado al estilo de buena parte de los liberales del XIX y del XX (o del XXI). Es un gran conocedor del diseño neotestamentario del buen pastor de una comunidad cristiana y alguien que clama contra el esperpento demasiado generalizado en que se había convertido la mayor parte de la institución clerical del XIX.

\section{d) La existencia religiosa cristiana y la actividad eclesial}

En su observación realista del funcionamiento de la Iglesia Galdós se encuentra con dos mundos de acciones distintos pero muy vinculados entre sí y arraigados en la sociedad civil española (no sólo en el contexto eclesial): la religiosidad popular y las acciones sacramentales.

- En las devociones populares contempla y admira su vertiente estética y de cierto valor espiritual, como son las albáes que escucha conmovido Tito en Tafalla (De Cartago a Sagunto) o las procesiones toledanas del Corpus, a las que asiste; pero no omite una fuerte crítica cuando reflexiona en diversas ocasiones sobre los desafueros de la Navidad española anticristiana:

«Llegó Navidad, llegaron esos días de niebla y regocijo en que Madrid parece un manicomio suelto. Los hombres son atacados de una fiebre que se manifiesta en tres modos distintos: el delirio de la gula, la calentura de la lotería y el tétanos de las propinas. Todo lo que es espiritual, moral y delicado, todo lo que es del alma, huye o se eclipsa. La conmemoración más grande del mundo cristiano se celebra con el desencadenamiento de todos los apetitos. Hasta el arte se encanalla. Los teatros dan mamarracho o la caricatura del Gran Misterio en nacimientos sacrílegos... No hay más que un pensamiento: la orgía» ${ }^{55}$.

\footnotetext{
${ }^{54}$ B. Pérez Galdós, Mendizábal (Madrid: Historia 16-Caja Madrid, 1994), 60-61.

${ }^{55}$ B. Pérez Galdós, La desheredada (Madrid: Cátedra, 2011), 239.
} 
El arte cristiano arquitectónico, pictórico y litúrgico le ofrece un especial interés; denunciando con mucha frecuencia sus carencias, o destacando su esplendor cuando lo merece.

- Respecto a las acciones sacramentales, como un simple esbozo de la teología galdosiana, sugeriríamos el tratamiento de los siguientes aspectos. El tema de la liturgia sacramental cristiana que está admirablemente tratado -descrito y valorado- en obras como Gloria, Rosalía, Ángel Guerra, Mariucha, etc.

Sobre todo, Galdós denota poseer una visión teológica avanzada (y, en consecuencia, crítica) del tema eucarístico y de su desarrollo usual en las iglesias. Con alguna frecuencia sus personajes asisten o se refieren a celebraciones de la Eucaristía, y esto de muy diverso modo. Unas, asumiendo la trascendencia del acto que discurre con alguna cercanía a lo que fue este tipo de acción en la primitiva iglesia, valorando el hecho de comulgar las especies sacramentales, incluso más allá del acto físico de tomarlas. Es la comunión que toman Nazarín en prisión, rodeado de delincuentes, o la que recibe Mita, a solas en el campo.

«Un ardiente anhelo de decir misa y de ponerse en comunicación con la Suprema Verdad le llenó toda el alma, y lo mismo fue sentirlo que verse revestido delante del altar, un altar purísimo, que no parecía tocado de manos de hombres. Celebró con inmensa piedad, y cuando tomaba en sus manos la Hostia, el divino Jesús le dijo: Hijo mío, aún vives. Estás en mi santo hospital padeciendo por mí... Algo has hecho por mí. No estés descontento. Yo sé que has de hacer mucho más» ${ }^{56}$.

O los diversos momentos en que, a punto de morir, algunos personajes reciben la visita y comunión de la Eucaristía en su propia casa (Mauricia, en Fortunata y Jacinta, Angel Guerra) o embarcados dando la vuelta al mundo.

«"Ya mis algibes están llenos del agua limpia de la verdad..., y para esto se vaciaron del agua corrompida de la mentira" -dice Binondo-; y Ansúrez añade: "-Ya sé, ya sé... Estás en franquía para vida mejor, ya has comulgado, ya tienes el práctico a bordo"»»"

${ }^{56}$ B. Pérez Galdós, Nazarín (Madrid: Alianza Editorial, 1998), 247. En cuanto a la vivencia eucarística de Mita (que recuerda la de Teilhard de Chardin en las soledades del Asia Central, La Misa sobre el mundo) ver La revolución de julio (Madrid: Historia 16-Caja Madrid, 1994), 77.

${ }^{57}$ B. Pérez Galdós, La vuelta al mundo en la Numancia (Madrid: Historia 16-Caja Madrid, 1995), 76. Podría verse el relato de la última Comunión de Mauricia, en Fortunata y Jacinta..., vol. II, 188-189. 
Y en otras ocasiones, las más, denunciando las sacrílegas celebraciones de Misas sin las mínimas condiciones de autenticidad teológica; como las que preceden a una acción violenta o guerrera o tiránica (La campaña del Maestrazgo. De Cartago a Sagunto).

Esta visión correcta (incluso avanzada) de la teología sacramental podría verificarse también a propósito de los sacramentos de la Penitencia o Perdón y del Matrimonio.

Galdós sorprende invirtiendo los términos clásicos de penitente y confesor en los Episodios Zumalacárregui y Prim.

«En este supremo trance, nunca visto, señor y padre mío - dice el presbítero-, yo me despojo de la autoridad que mi religión me da para perdonar los pecados, seguro de que Dios la trasfiere a Vd., haciendo del penitente el sacerdote. Hombre recto y cabal en todo tiempo, ahora es usted un santo. Ante el santo me humillo yo, y le pido perdón ${ }^{58}$. «"A mí me ha enseñado mi maestro Don Ramón Lagier que cuando tenemos el alma pesarosa, por culpas cometidas, no debemos esperar a encontrar cura, pues para esto cualquier persona natural es cura..., o, como quien dice, que el sacerdocio no debe ser oficio de unos cuantos sino función de todos". A lo que Santiago -más ortodoxo- objeta: “`Valientes disparates te ha enseñado tu Don Ramón!"” ${ }^{59}$.

Y la misma visión sacramental abierta aparece en cuanto a la verificación religiosa del matrimonio. En concreto, sucede, por ejemplo, en la celebración de los matrimonios de Rosario y Pepe Rey, de Mita y Leo, de Santiago Íbero hijo y Teresa Villaescusa, de Esperanza y Diego Ansúrez y de otras parejas semejantes cuyo enlace matrimonial escapa a todas las normas canónicas y se le otorga, sin embargo, una alta valoración humana, religiosa y cristiana.

«-(Rosario): "Señor que adoro, Señor Dios del mundo y tutelar de mi casa y de mi familia; Señor a quien Pepe también adora; Santo Cristo bendito que moriste en la cruz por nuestros pecados: ante $\mathrm{Ti}$, ante $\mathrm{Tu}$ cuerpo herido, ante Tu frente coronada de espinas, digo que éste es mi esposo, y que después de Ti es el que más ama mi corazón; digo que lo declaro mío, y que antes moriré que pertenecer a otro. Mi corazón y mi alma son suyos. Haz que el mundo no se oponga a nuestra felicidad y concédeme el favor de esta unión, que ha de ser buena ante el mundo como lo es en mi conciencia.

\footnotetext{
${ }^{58}$ Pérez, Zumalacárregui..., 16.

${ }^{59}$ B. Pérez Galdós, Prim (Madrid: Historia 16-Caja Madrid, 1996), 181.
} 
-Rosario eres mía -exclamó Pepe con exaltación-. Ni tu madre ni nadie lo impedirá" ${ }^{60}$.

\section{Conclusión}

Me gustaría introducir aún otros temas menores, pero igualmente luminosos de la teología galdosiana, pero los límites de brevedad impuestos a esta comunicación me impiden hacerlo. Termino, pues, mi exposición con estas sucintas conclusiones:

$1^{\text {a }}$. Existe un denso y abundante pensamiento religioso y originalmente cristiano en el conjunto de la producción escrita de Benito Pérez Galdós, con una coherencia interna absoluta en su múltiple tratamiento temático a lo largo de los cincuenta años de escritura. Este pensamiento es el más amplio y pormenorizado (respecto a los demás escritores de nuestro realismo literario) y probablemente es muy superior al que hallamos en el realismo de la literatura coetánea francesa, inglesa y rusa.

$2^{\text {a }}$. El pensamiento religioso cristiano de Galdós no es ajeno ni paralelo al análisis antropológico e histórico (hispano y universal), ni a la estética literaria, que definen fundamentalmente al autor y lo sitúan en la cumbre de la novelística moderna. Muy al contrario, se halla inmerso y perfectamente integrado en la totalidad de la creación de tipos, de obras y de situaciones, constituyendo, sin duda, una clave imprescindible de comprensión del valor de esta creación.

$3^{\text {a }}$. Este pensamiento debidamente analizado permite al estudioso literato y teólogo establecer - a posteriori- una sistematización teológica temática de excepcional categoría por sus contenidos y correspondencias. De tal forma que se puede hablar de un cierto cuerpo de teología sistemática en la obra de Galdós (que no es precisamente teólogo).

Descubrimos en su obra una teología fundamental y básica, pero abierta, dotada de intuiciones sorprendentes que pudieran acercarse a la antropología cristiana de Rhaner y, a la vez, a los postulados de la mejor teología de la liberación y del pensamiento teológico más actual. Una teología que tiene, sobre todo, desde el punto de vista metodológico y aproximativo para el lector, el mérito de ser extraordinariamente narrativa y simbólica.

En todo caso es obvio para mí que Don Benito pertenece por derecho propio al patrimonio cultural español y universal de signo cristiano y que, en el

\footnotetext{
${ }^{60}$ Pérez, Doña Perfecta..., 188.
} 
ámbito de la teología, debiera considerarse como una notabilísima aportación a la teología literario-narrativa y simbólica.

\section{Bibliografía}

Citas textuales de obras de Galdós en este artículo.

De las novelas: La fontana de oro (1870), El audaz. Historia de un radical de antaño (1871), Rosalía (1872) Doña Perfecta (1876), Gloria (1878), Marianela (1878), La desheredada (1881), Ángel Guerra (1881), Tormento (1884), Fortunata y Jacinta (1885), Tristana (1892), Torquemada en la cruz (1893), Nazarin (1896).

De los Episodios Nacionales: Napoleón en Chamartín (11873), Cádiz (1874), La batalla de los Arapiles (1875), Siete de julio (1876), El terror de 1824 (1878), Un faccioso más y algunos frailes menos (1879), Zumalacárregui (1898), Mendizábal (1898), Vergara (1899), Tormentas del 48 (1901), Aita Tettauen (1904), O'Donnell (1904), Carlos VI en La Rápita (1905), Prim (1906), La vuelta al mundo en la Numancia (1906), La primera República (1911).

De las piezas teatrales: La de San Quintín (1893), Alma y vida (1903), Electra (1903), Amor y ciencia (1906), Pedro Minio (1908), Celia en los infiernos (1913).

De otras: El sentimiento religioso en España (1884), Carta de 4/7/1916 (Casa Museo Galdós. Las Palmas, documento 8085), Escritos inéditos. 